\title{
Atlantis: a Grain of Truth Behind the Fiction?
}

\author{
Massimo Rapisarda ${ }^{1,}$ * \\ 1 ENEA; massimo.rapisarda@enea.it \\ * Correspondence: massimo.rapisarda@enea.it; Tel.: +39-0694005755
}

\begin{abstract}
The legend of Atlantis was almost certainly invented by Plato to promote the political ideal of his masterwork The Republic, while praising the heroism of his own ancestors. This paper suggests that, in assembling the story, Plato might have reworked the myth of the foundation of Egypt, attributed to divine invaders bringing agriculture and unknown technologies to the country. The key issue explored is the curious coincidence between the period of the alleged foundation of Egypt (according to traditional Egyptian sources) and some remarkable events that characterized the end of the Ice Age. Indeed, besides the sudden increase in temperature and the consequent rise in sea level, the period was also marked by the birth of agriculture and the appearance of totally new technologies in diverse Near Eastern locations. The memory of these events would have been handed down through the myth of the foundation of Egypt and, through this, to Greek culture, enabling Plato to exaggerate the antiquity of his noble ancestors while embellishing the characteristics of the invaders. Such occasional technological leaps may also have occurred elsewhere in the world, for instance on the deltas of the Indus or the Yangtze, driven by the same change in climate that affected the whole planet. Although today there is no archaeological evidence of such events besides in the Near East, the article suggests that the possible discovery of obsidian in a submerged site would be a strong indication of a local technological leap. To this end it examines, amongst suspected Mediterranean sites, some flooded islands in the Strait of Sicily, which, lying on the route to Pantelleria, may retain traces of ancient obsidian exploitation.
\end{abstract}

Keywords: Atlantis; Obsidian; Pantelleria; Strait of Sicily; Plato

\section{Introduction}

The myth of Atlantis stems from two late Dialogues of Plato (Timaeus and Critias) ${ }^{1}$ [1], in which the philosopher wrote of a powerful Mediterranean empire that had conquered Egypt about nine thousand years earlier, before being defeated by the primordial Athenians and then destroyed by a cataclysm. The two dialogues praise the perfect social structure of the original Athenian polis (mirroring that described in Plato's masterwork, The Republic) and the heroism of the founding fathers of Athens (from whom the aristocrat Plato descended), giving the immediate feeling that the philosopher forged the legend of Atlantis to support his political ideal and celebrate his ancestors. ${ }^{2}$

Inventing stories to sustain a thesis has always been a common practice among writers. And since the more the legends are believed, the more they support the author's assumptions, various techniques have been developed to substantiate the forgery. The trick of modifying true stories (or stories believed to be true) by inserting one's own inventions in them is widespread and boasts

\footnotetext{
1 The Platonic text analysed in this article is the translation by W. R. M. Lamb [1].

2 Plato was the son of Ariston (whose pedigree stretched back to the first kings of Athens and, through them, to the god Poseidon) and Perictione (belonging to another prominent family, related through Critias to Solon, the legislator) [2].
} 
illustrious examples. Both the Aeneid and the Orlando Furioso, to name just two classical cases, modified popular legends to glorify the ancestry of their commissioners. ${ }^{3}$

Scholars' scepticism about the possible existence of Atlantis is therefore well justified. The present article takes for granted the 'invention' of the legend, but attempts to analyse whether it might contain references to actual events, even though artfully retouched. The working hypothesis is that Plato inserted the propaganda elements (the social structure of the ideal polis and his ancestors' heroism) in a narrative of episodes believed to be real by his countrymen (the recipients of his message), to render them more credible.

Plato's fellow citizens had the sense of an obscure grand past, witnessed by the mysterious cyclopean walls still visible on the acropolis, although they were not sure about how far it dated back. What they seemed to know more accurately was the age of Egypt: according to Herodotus, the human kingdom of Egypt (which followed the divine one) began 341 generations before his visit to Thebes (Book II, 142-144) [3]. With a generation gap of 25 years this meant about 8500 years earlier (plus the duration of the divine realm).

The Egyptians, at the time considered the oldest people in the world, ${ }^{4}$ themselves provided further support to the myth of a vanished ancient civilization. Their chronologies reported that their first pharaohs had been gods [5] (p.18) who came from the West, a polite way of saying that their kingdom had begun when foreign conquerors with 'magical powers' (i.e. unseen technologies) arrived in the area, bringing agriculture and new knowledge.

The whole story could therefore result in a syncretism blending mythological legends and impressive natural phenomena, to be placed in a period well-suited to the beliefs of the time. For example, it could have mixed the myth of a flood hitting a primordial society which had grown so powerful and wicked as to deserve divine punishment (rather common among ancient cultures, including Greece) with the shocking experience of the earthquake cum tsunami that erased the city of Helike in the Gulf of Corinth in 373 BC. (Paus. 7.24.12) [6]. ${ }^{5}$

In short, in Plato's times, legends regarding lost civilizations and the time of the 'divine' birth of Egypt were somewhat widespread among literate Athenians. The thesis supported in the present article is that Atlantis was the name given by Plato to the land where the god-founders of Egypt originated. To this extent, note that according to the likely independent view of Diodorus of Sicily ${ }^{6}$, the Atlanteans were an extremely refined and pious people because the gods had been born among them: their first king had been Uranus, a god who taught them agriculture [7] (Book III, 56, 3). For the sake of completeness, Appendix A summarizes Plato's and Diodorus' references to the geographical position of Atlantis (although their credibility is questionable), but for a complete treatment of the mythological sources it is recommended the book L'Atlantide et la mythologie grecque [8] by hellenist Bernard Sergent.

Identifying Atlantis with the land of Egypt's founders would solve the problem of the passing down of the myth to Plato's days (through their traditional mythology), while coercing the epoch of the episode. Let us focus on the date set by Plato for the purported flourishing of Atlantis (coherent with Herodotus' estimate and with the antiquity that Egyptians traditionally attributed to themselves): it would correspond roughly to 11,500 years ago (9500 BC), a period of substantial climatic upheaval and archaeological novelties.

\footnotetext{
${ }_{3}$ Virgil's Aeneid attributes the origin of the gens Julia (the family of Caesar and Augustus) to Aeneas of Troy. In Ariosto's Orlando Furioso, a poem dealing with the Carolingian cycle, Bradamante and Ruggero are supposed to be the founders of the Este family.

${ }^{4}$ Egyptians themselves estimated their own antiquity to be even older than that claimed by Herodotus [4].

${ }^{5}$ Even the demise of Santorini could have contributed to inspire the story (supposing that Plato knew about it).

${ }^{6}$ Although Diodorus probably knew the Platonic Dialogues, he does not seem to have drawn from them. His main source about Atlantis, quoted by Diodorus himself, was Dionysius, almost certainly Scytobrachion, a mythographer of Mytilene who lived and taught in Alexandria in the second century BC.
} 
This is the key problem with the story: this was the end of the Ice Age, a time before agriculture when humans were still engaged in hunting and gathering, and therefore an unlikely time for an 'advanced' human society like the one described by Plato. What do we know about this crucial period, the end of the Ice Age? Are there any environmental factors which could help us explain elements of the myth of Atlantis, in particular its destruction by flooding and earthquake/volcanic eruption?

\section{The end of the Ice Age}

The Earth's climate has not always been the same. For example, in the last half a million years there have been four ice ages interrupted by four much shorter interglacial periods [9]. The last ice age began more than one hundred thousand years ago and peaked around twenty thousand years ago, whereupon the temperature began to rise [10]. During this transitional phase, seafaring spread throughout the Mediterranean and became rather sophisticated. Seventeen thousand years ago this enabled the colonization of Sardinia [11] and the development of the practice of deep-sea fishing [12]. But thirteen thousand years ago, at the beginning of the Younger Dryas ${ }^{7}$ a quantum leap in Mediterranean navigation occurred, with the colonization of Cyprus (Fig. 1), which involved crossing forty nautical miles [14], and with the establishment of 'regular' sea routes for shipping obsidian from the island of Melos to Argolis in mainland Greece [15].

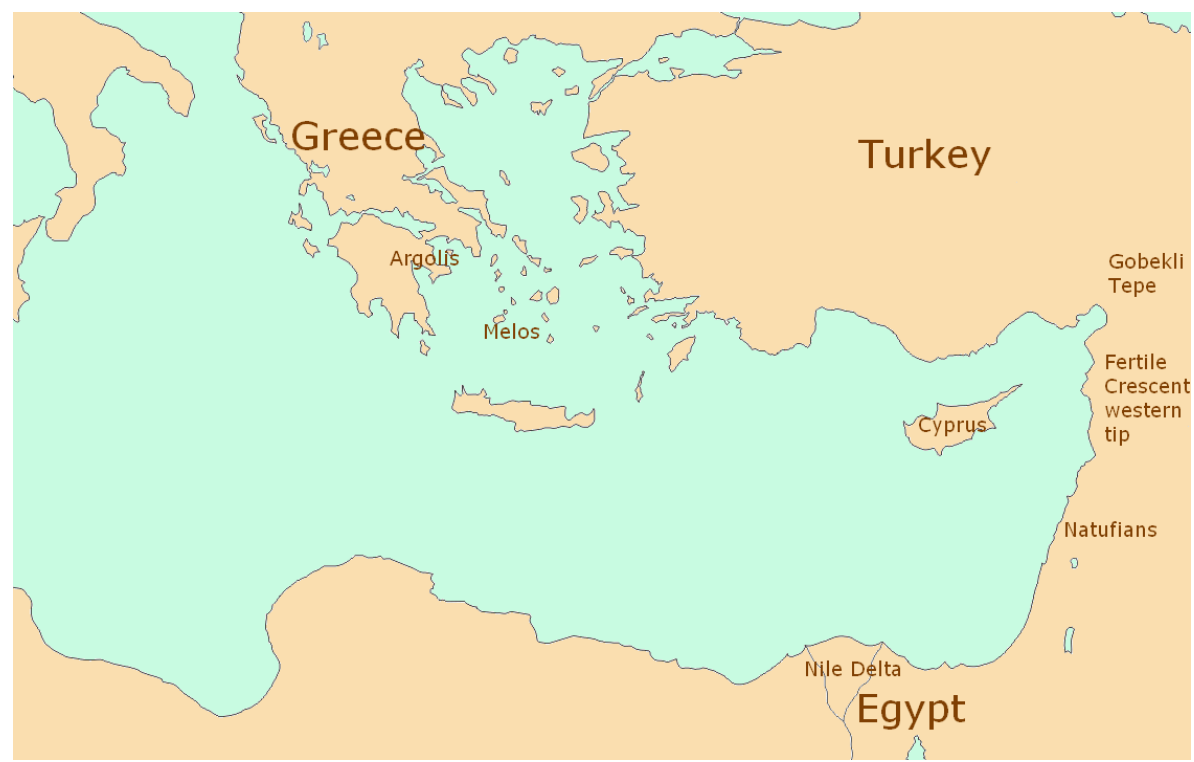

Figure 1. Location of some early technological breakthroughs (map from d-maps.com) [16].

In the same period, although apparently still hunters/gatherers, humans were able to coordinate themselves to build and decorate with bas-reliefs a large stone temple at Göbekli Tepe in Turkey [17]. A little further south (Fig. 1), in the western tip of the Fertile Crescent, communities began to select grains to grow [18], heralding the beginnings of agriculture. In fact, although wild cereals had already been part of the human diet since the Last Glacial Maximum [19], prior to thirteen thousand years ago when the first domestic species appeared, we cannot state if they were planted or spontaneous. Just a little further south, between current Lebanon and the Sinai, in the arc of time between the two Meltwater Pulses (MWP) $1 a$ and $1 b,{ }^{8}$ another group of humans became sedentary for the first time. In fact, the first stone houses appeared in Natufian villages [20],

\footnotetext{
7 The Younger Dryas was a period of intense cold that interrupted the trend of general warming at the end of the Ice Age for about 1300 years [13].

${ }^{8}$ Between 14,500 and 11,500 years ago. The Meltwater Pulses (MWPs) were sudden warming episodes that caused swift ice melting on the poles and therefore an equally rapid rise in sea level. During the last deglaciation phase there were two important MWPs, classified as MWP 1a and MWP 1b.
} 
containing tools and ornaments never seen before [21]. They were even able to cook the first recorded bread more than fourteen thousand years ago [22].

In practice, from the Aegean Sea to the Sinai, various revolutionary innovations, both marine and terrestrial, altered the life of humans shortly after MWP 1a. They were probably detached from one another, reinforcing the suspicion that these lifestyle changes were due to the abrupt climate change: the average temperature suddenly rose to today's level, summers became hotter and precipitations varied in intensity and frequency. ${ }^{9}$ Longer summers and calmer seas extended the navigation season, allowing the refinement of maritime techniques. Perhaps in southern Turkey the wild grain no longer grew spontaneously and it was necessary to irrigate the soil or to select the lands to grow it. Certainly, the ingenuity to exploit local resources was not lacking a little further south, where, for the first time, a people (the Natufian) was able to become sedentary.

Worldwide, such a warm climate had not been seen for fifty thousand years [23]. Necessity is the mother of many inventions, thus the hypothesis that the innovations mentioned above were independent responses to altered climatic conditions is plausible; but why have their traces been found only in the Near East? Where are the signs of human ingenuity in the rest of the world? After all, climate warming affected the whole planet.

The answer to this question could lie in a side effect of the higher temperatures: the rise in the sea level. During the transition from glacial to interglacial, many coastal areas were flooded by the sea and had to be abandoned, sharing the same fate as many flat islands which rapidly became part of the seafloor. In other words, the human tendency to live along the shoreline had an obvious consequence for the location of archaeological sites: it is likely that many areas inhabited before the onset of the interglacial period lie on the seafloors that constituted the coast of the time [24], providing a good explanation for the lack of findings to date.

The flourishing of navigation and the density distribution of the Natufian huts over time (much higher during the warm period than in the subsequent cold one, according to Munro [25]) suggest that changes were more probably an adaptation to the warm Bølling-Allerød period rather than to the cold Younger Dryas. In other words, it is likely that it was the arrival of heat that caused the revolution in human habits and not the onset of the subsequent cold period. But can we really state these climatic changes occurred with such precision?

The ratio between two oxygen isotopes $\left(\mathrm{O}^{18} / \mathrm{O}^{16}\right)$ in the skeleton of foraminifera, organisms stratified on the ocean bottom, is correlated to the size of the glaciers up to five million years ago [26]. The succession of ice ages revealed by foraminifera is confirmed by the measurements of $\mathrm{O}^{18} / \mathrm{O}^{16}$ trapped in the Antarctic ice [9] for the last 800,000 years, and, in the Arctic ice [27] for the past 120,000. Obviously, the details increase as we approach the present day, thus the temperature trend in the last twenty thousand years is known quite precisely. There is also a broad agreement between the Antarctic and the Arctic data, confirming that the largest climatic events regarded the whole planet [28].

The change in average temperature between glacial and interglacial periods (which could reach $10{ }^{\circ} \mathrm{C}$ ) was not the sole difference between the two climatic periods. The water accumulated in the continental glaciers was obviously missing from the oceans, which were emptier and thus shallower: at the glacial maximum the sea level was 120 metres lower than today (Fig. 2). As a result, the coastline was different from today's: several seafloors were emerged and fit for living. Since the territorial occupation followed the drift in the shoreline, the sea level rise also had repercussions for those living further inland. In short, since the last ice age, climate change has probably caused conflicts, migrations and aggregations among human populations.

At the Last Glacial Maximum (around twenty thousand years ago) northern Europe was almost uninhabitable [29], while the Mediterranean basin had a relatively temperate climate (see fig. 5). The North-Western Sahara, however, was as dry as today, apart from the coastal strip from Morocco to Tunisia, which enjoyed the Mediterranean climate [30].

\footnotetext{
${ }^{9}$ Bølling-Allerød is the name of the warm period that followed MWP 1a and lasted about fifteen hundred years. In Europe, many forests became populated, having turned into favourable hunting grounds.
} 


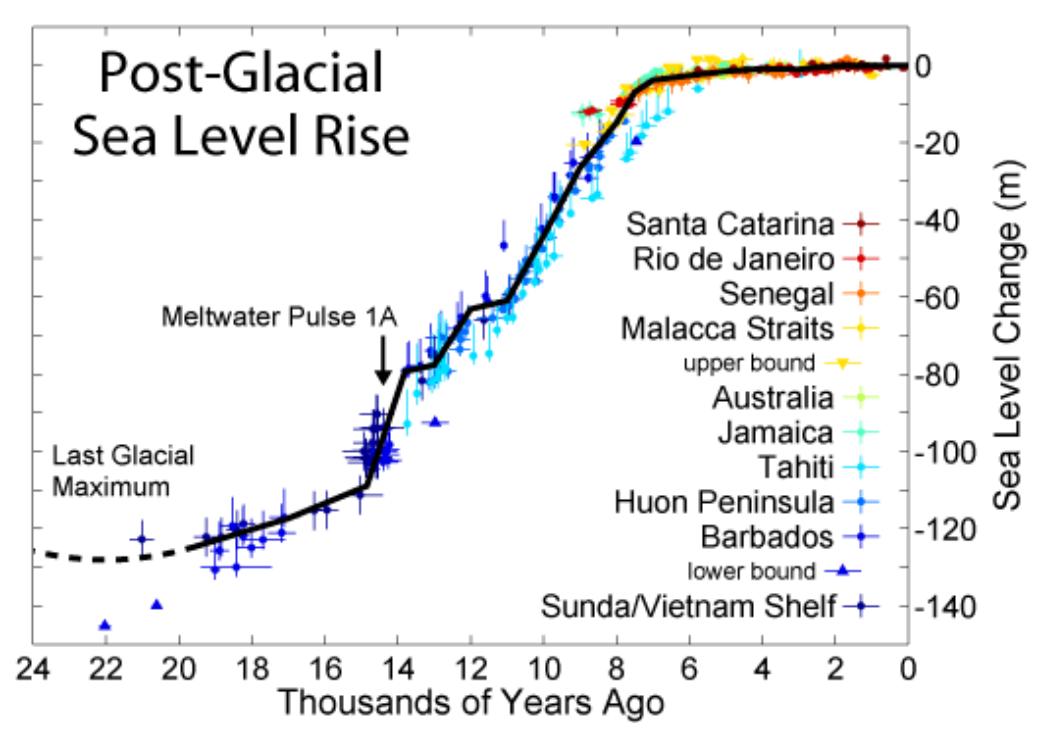

Figure 2. Sea level rise from the Last Glacial Maximum to today, based on data from K. M. Fleming (2000) [31], K. Fleming et al. (1998) [32], and Milne, Long, and Bassett (2005) [33] (image created by Robert A. Rohde / Global Warming Art).

Eighteen thousand years ago, the temperature began to rise and, in the following ten thousand years, the melting of glaciers raised the sea level by about 120 metres, up to the current value [26]. The rise in sea level was not uniform, but characterized by sudden increases, including the two episodes already mentioned: MWP 1a and 1b. Fairbanks [34] recorded extensive evidence of the two pulses in Barbados. Their ${ }^{14} \mathrm{C}$ timing was corrected a year later by E. Bard et al. [35] with U-Th measurements (Fig. 3). The two Meltwater Pulses were later confirmed in China by Wang et al. [36] using data from the Hulu cave.

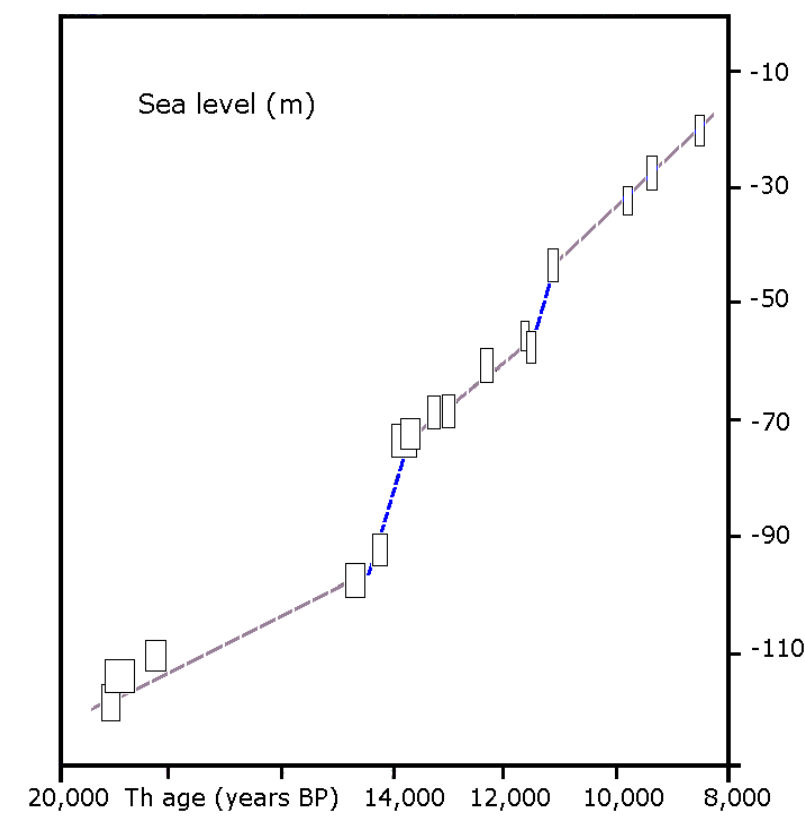

Figure 3. MWP 1a and $1 \mathrm{~b}$ (in blue). Sea level in function of the ${ }^{230} \mathrm{Th}$ age, inferred from Barbados coral reefs. The U-Th age errors are quoted at $2 \sigma$ level (from E. Bard, Hamelin, and Fairbanks 1990) [37].

According to these observations, during MWP 1a (around 14,300 years ago), the sea level rose from -95 to -75 metres, while during the later MWP $1 \mathrm{~b}$ (about 11,500 years ago) it rose from about -60 to about -45 metres compared to the present value. Liu and Milliman [38], who reviewed the Caribbean data of Fairbanks [34] and E. Bard, Hamelin, and Fairbanks [37], stated that the MWPs 
were fast phenomena, happening in less than two hundred years. Even faster according to Steffensen et al. [39], who later examined the Greenland ice and claimed that the Pulses had lasted between three and ten years.

MWP 1a is often considered the indicator of the end of the Ice Age, because in the following Bølling-Allerød period temperatures were much higher and similar to current ones. However, thirteen thousand years ago, the cold climate suddenly returned and temperatures became glacial again for about thirteen hundred years, in the period known as the Younger Dryas [13]. The Younger Dryas ended abruptly too with MWP 1b, which marked the beginning of the Holocene, the period we currently live in (Fig. 4).

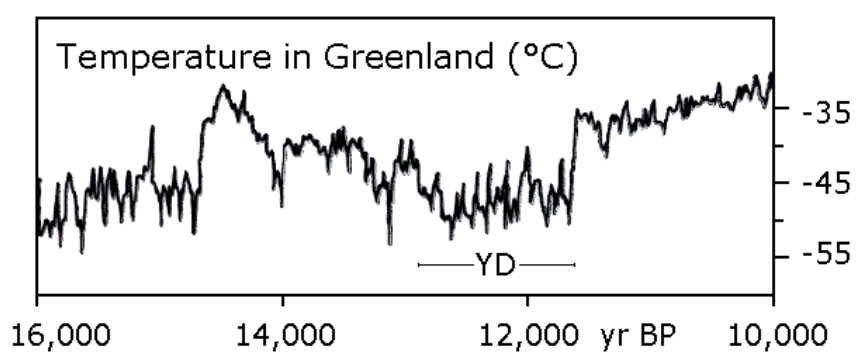

Figure 4. The temperature in Greenland during the 'thaw'. Note the sudden increase at the end of the Younger Dryas, in correspondence with MWP 1-b (from Alley 2000) [13].

Fig. 5 summarizes the climatic conditions of the Mediterranean basin prior to fifteen thousand years ago. The coastline, calculated by the National Geophysical Data Center [40] for the glacial maximum, was still roughly valid, giving an idea of which territories were most suitable for inhabitation. It is likely that among them were several emerged seafloors [23].

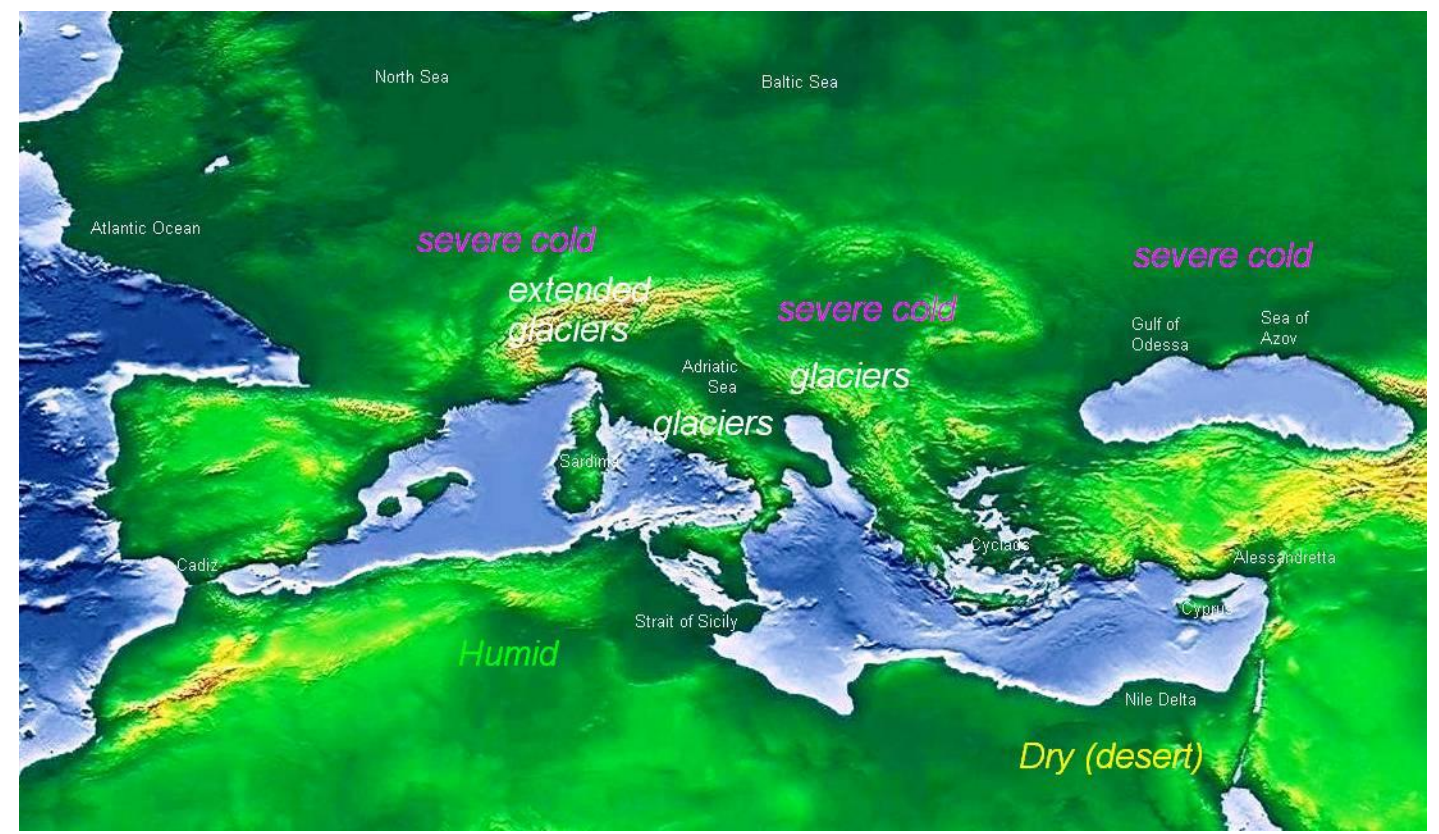

Figure 5. The climate of the Mediterranean basin before MWP 1a (modified map from GLOBE 1999) [40].

In the northern hemisphere, common sense suggests that the preference went to the more fertile southern plains populated by herbivores to hunt, and to coastal areas. Just before MWP 1a the Sahara became suddenly moist [41] and forests filled the Atlas Mountains, while prairies and savannahs covered the Western Sahara [30]. The former desert became populated by gazelles, elephants and lions [42] and humans followed soon after. This wet period, known as the African Humid Period (AHP), ended about six thousand years ago [43], much later than the onset of the Holocene. 
The shoreline depicted in fig. 5 was valid before MWP 1a, that is, until the sea level was at least 90 metres lower than today. Then the sea level rose quickly and people had to move away. While they still could, they simply moved more inland, but when the sea submerged inhabited islands, they had to leave them.

The flooding that marked the end of the Ice Age did not come alone but was accompanied by terrible volcanic eruptions. It was not bad luck, but the result of the dynamics of continental plates: when the ice deposited on a plate melts, the reduced weight on the plate generates instability. Because of these tensions, along the plate boundaries the layer of the Earth's crust can deform to the point that it cracks, allowing the underlying magma to find a passage towards the surface and generate new volcanoes. For their part, volcanic eruptions themselves cause climatic variations. Usually they disperse ash in the stratosphere, increasing the reflection of sunlight and causing cooling, although sometimes they can also emit large amounts of methane or $\mathrm{CO}_{2}$, thereby increasing the greenhouse effect.

The cause and effect relation between climate and eruptions is rather complicated, but it is well known that the planet's climate changes have always been accompanied by an increase in volcanic activity. This correlation was observed during the Quaternary [44, 45], and has been confirmed in the central Mediterranean [46]. It is no coincidence that the beginning of the Holocene was accompanied, 11,300 years ago, by a terrible eruption, witnessed by the largest peak of $\mathrm{SO}_{4}$ (Fig. 6) recorded in Greenland during the last twenty thousand years [47].

In fact, it is the explosive activity that is related to climatic changes, as shown by Zielinski et al. [47] by examining the data of the last hundred thousand years. For example, in the Mediterranean basin only, in coincidence with the highest variations in sea level, the number of large explosive eruptions tripled, reaching the frequency of three per millennium [48].

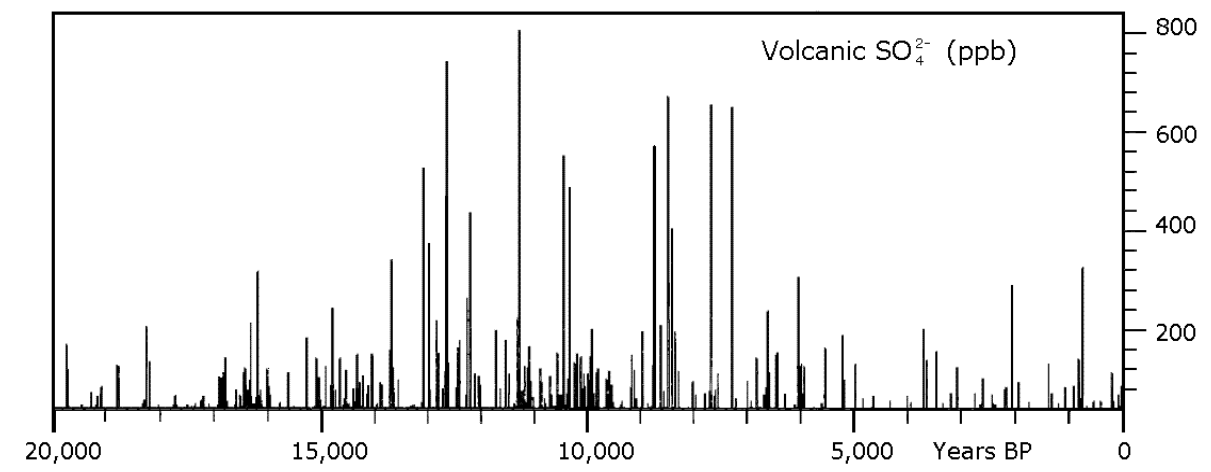

Figure 6. Volcanic $\mathrm{SO}_{4}>40 \mathrm{ppb}$ in the past 20,000 yr (from Zielinski et al. 1996) [47]; data from the Greenland Ice Sheet Project 2 analysed through an empirical orthogonal function decomposition method (Mayewski et al. 1994) [49]. Note the high density of episodes between fifteen and eight thousand years ago.

On the whole, the geological and climatic disasters of the end of the Ice Age may well justify not only the flourishing of innovations that occurred then in the Near East, but also the birth of the collective memory of that catastrophic period. Plausibly, similar cultural leaps could have happened elsewhere in geographically similar regions of the world and gone unnoticed just because their submerged sites have not been searched.

In this broad contest, the myth of gods bringing agriculture and new technologies to nascent Egypt could simply relate to the arrival of an 'early' Neolithic people in the region (perhaps displaced by one of the cataclysms that afflicted the epoch). The memory of the event, passed down through the Egyptian tradition and then through Herodotus' Histories, could have made up the core of Plato's legend. Obviously, accepting such a chronology would imply that many aspects of the fanciful Atlantis civilization must be the sheer fruit of the philosopher's fantasy. 


\section{Is the claimed explanation of the myth compatible with Egyptian history?}

The history of ancient Egypt is well established. The pharaoh who unified the country lived around five thousand years ago (5000 BP). At that time, the tribes that occupied Egypt were grouped into the kingdoms of the North and of the South, which the legendary Menes unified into one state, initiating the so-called Dynastic period. This period was preceded by the Predynastic one, lasting around three millennia, which is conventionally divided into "early", and "late" (from about 6000 to 5000 BP), during which the two kingdoms of the North and South already existed. The Predynastic period was, in turn, preceded by several Palaeolithic cultures, whose remains date back to tens of thousands of years ago.

Before $10500 \mathrm{BP}$, the Egyptian desert was hyper-arid, as it has been for the last six thousand years [50,51]; during this period traces of human occupation were concentrated along the banks of the river [52], although no data are available for the Nile delta. In the following period, from the early Holocene (10500 BP) to the first phase of the early Predynastic (7300 BP), human occupation was affected by the presence of Asian monsoon rains and by the movement of the Inter-Tropical Convergence Zone $[53,54,51]$. During this phase the Nile banks were a rather hostile environment, and humans preferred to live in the savannah then present in today's desert [55]. Later, the return of the desert forced the repopulation of the river banks (and probably drove the foundation of the two kingdoms).

The first evidence of plant food production (mainly wild wheat and barley) dates back to around 11500 BP in the Fertile Crescent $[56,57,58]$ (not too far from Egypt). The "core area" hypothesis [59, 60] of a few "founder crops" selected and domesticated in a single region [61] is the orthodoxy, but it is not unlikely that cultivation started in different areas, conditioned by the regionally diverse subsistence strategies of different Pre-Pottery Neolithic groups [62]. Although there are not enough data to prove that processes developed in parallel, the hypothesis of independent domestications and cultivations means that the local climatic conditions would have been an important driver of the Neolithic revolution.

In Egypt, cultivation developed as early as 8000 BP in the Sahara, west of the Nile valley [63] and regarded mainly sorghum and wild millet. Agriculture, however, became common along the Nile only during the Predynastic, when species native to the Fertile Crescent (wheat, barley, goats, sheep, cattle and pigs) became widespread [64], bearing the clear mark of their geographical origin. The most likely location through which these crops and animals were introduced was the Nile Delta [65]. The recorded history of the introduction of agriculture therefore justifies the Egyptian myth of founder gods (foreigners) bearing cultural novelties. Herodotus would have learnt about the legend during his travels to Egypt and written about it in his Histories, from which Plato could have drawn.

However, there is a discrepancy with the timing. Herodotus claimed to have computed the age of Egypt from the 341 statues of high priests that he pretended to have seen, but more probably he relied on local tradition, based on the king lists. The Aigyptiaka (History of Egypt) of Manetho is the most popular king list known, but also the most chronologically unreliable. It claims that the first kings were gods, but stretches their arrival to around thirty thousand years BC. Its chronology, accessible only through quotations by other authors (Josephus, Africanus, Eusebius and Syncellus), is best known through "Contra Apionem", a polemical libel by Flavius Josephus written to demonstrate the greater antiquity of the Jewish religion with respect to the Greek one, and thus intrinsically untrustworthy.

Among the sources that were possibly available to Manetho, two have come down to us, although in a damaged state: the Royal Canon of Turin and the Palermo Stone. The Royal Canon of Turin [66] is a hieratic papyrus found in Luxor, today fragmented and deprived of its initial and final parts. Dating back, almost certainly, to the time of Ramses II (XIII century BC), it lists the nineteen dynasties that preceded its compilation.

Far more important for the early history of Egypt is the Palermo Stone [67], the largest and most readable fragment of seven, all apparently belonging to the same stele. The stele, known as the Royal Annals of Ancient Egypt [68], was probably a single stone two meters long and half a meter high, placed in an unidentified temple during the Fifth Dynasty (ca. XXIII century BC), which 
reported year by year, along eight engraved rows, the height of the Nile flood and events to be remembered. Like the Canon of Turin, the Royal Annals include all previous dynasties preceding their making and seem to have had a more practical than apologetical function (the annual registration of the height of the Nile flood determined the incidence of taxation). The Annals, like the Aigyptiaka, show a long series of pre-unitary kings, whose alleged number, obtained by dividing the length of the stele by the width of the boxes, would push back the pre-Dynastic period one or two thousand years earlier than is currently assessed. Note that the first kings were gods, also according to the Royal Annals.

To sum up the facts reported in the previous paragraphs, it seems therefore quite reasonable that Plato could have used the Herodotus' tale to create his myth and located it in a period that sounded acceptable to his fellow citizens - a few thousand years earlier than is today assessed.

The onset of agriculture along the banks of the Nile is indisputable, but is there any chance that there was an early autonomous Neolithic culture in the delta? In terms of human habitation, the Nile delta remains the least understood part of Egypt's Early Holocene landscape, owing to millennia of sedimentation and constant reuse of arable land (Wengrow) [69]. The lateness of the first recorded occupation of the delta, belonging to about $7000 \mathrm{BP}$, has been usually attributed to environmental factors like regional climate changes and fluctuating Nile flood stages [70, 64], but Stanley and Warne [71], thanks to a rather detailed geological investigation, have proposed that initiation of farming settlements was strictly related to the presence of cultivable river silt, in turn linked to the sea level. They claim that it was the end of the eustatic sea rise (and of the marine transgression), which occurred around $7000 \mathrm{BP}$, that allowed the deposition of river silt in the region. They also opine that before $7000 \mathrm{BP}$ the steeper gradient from Cairo to the sea thwarted silt deposition.

They also note that at the Last Glacial Maximum (LGM) (around 18000 BP) the Nile shoreline was located near the present shelf break, about $50 \mathrm{~km}$ north of the present coast. However, Stanley and Warne assume a monotone sea level rise since the LGM and do not consider the breaks in eustatic sea rise that followed the two Melt Water Pulses in 14000 and 11000 BP (see fig. 2). Interestingly, these two breaks lasted one millennium each, during which the claimed conditions for silt deposition were fulfilled (absence of marine transgression and a gentler gradient, due to the greater distance from Cairo). In other words, it cannot be excluded that the delta's final strip was fertile land during the millennium following each MWP.

Kuper and Kröpelin [52] catalogued hundreds of radiocarbon-dated Egyptian sites and grouped them geographically. Their physical distribution confirms the correlation between the onset of desertification and the gathering of tribes along the Nile, and above all, shows a stream of ancient technological inventions flowing in time from north to south. Lack of data limits information about the initial settlements in the delta and on the coast, but the overall geographical pattern is evident: new technologies spread from the north, implying that their source had to be in the northern regions, even in times when these were supposedly uninhabited (not forgetting that these sites should be searched for underwater, which has not yet been done). In conclusion, the clues suggesting that the Egyptian coast and the Nile delta could have been inhabited much earlier than is today assessed should not be lightly neglected - the southern margin of the Mediterranean Basin along coastal North Africa is essentially terra incognita for understanding the course of Neolithic emergence (Zeder) [72]. Even Herodotus' timing of Egypt might not be so absurd.

\section{In search of Atlantis}

Although an unknown people living in the Fertile Crescent (or even in the Nile delta) are the most verisimilar candidates to impersonate the gods who brought civilization to Egypt, the climatic changes that occurred between fifteen and eleven thousand years ago regarded the entire northern hemisphere. More than ten thousand years ago, along three of the largest Asian rivers (the Yangtze, Indus and Tigris-Euphrates), agriculture emerged independently [73, 74, 18]. Some time later, the same floodplains hosted the oldest human civilizations. It is enticing to imagine that along the corresponding coastlines (today submerged) a precursor phase could have taken place during the deglaciation process. Broadly speaking, eleven thousand five hundred years ago, there might have been several "Atlantises" (some modern authors proposing them in diverse distant locations may 
actually be right), although none of them could have actually been related to Egypt or to the Greek culture.

In theory this relation was instead within reach for peoples living in the Mediterranean area. Indeed, although less likely, it cannot be ruled out that some of the innovative practices recorded in the Near East twelve thousand years ago were replicated somewhere else along the Mediterranean coast, driven by similar geographic and climatic conditions. To this extent, the seabed lying south of the $38^{\text {th }}$ parallel (see fig. 7) are the most indicated.

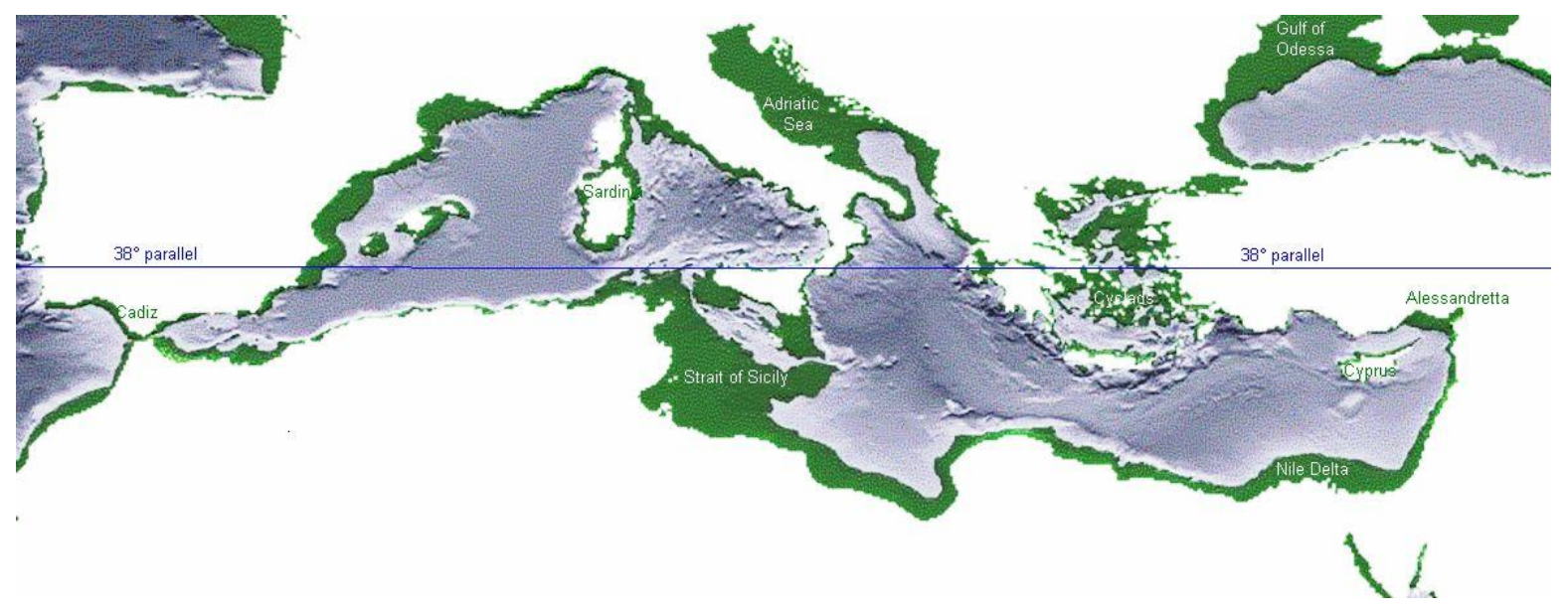

Figure 7. The Mediterranean seafloors emerged during the Last Glacial Maximum (in green).

In fact, many authors have already pointed to some of these regions as possible sites for Atlantis, supporting their choices with ingenuous arguments To enumerate the suggested locations is beyond the scope of this article, but it is likely that future underwater archaeological discoveries on the Mediterranean seabed will reinforce interest in the Platonic myth.

Nevertheless, among the possible candidates is a region where the hypothesis can be tested in a rather straightforward way, thanks to the presence of an obsidian source: the seabed of the Strait of Sicily. To this extent, two lucky accidents seem promising for the investigation:

a) The seabed of the Strait of Sicily is geologically rather quiet: it is almost possible to reconstruct the past shape of most of its coastline, taking into account only the eustatic factor (meaning that the isobath surfacing at a given sea level drop corresponds to the shoreline of the matching time) [4].

b) The island of Pantelleria, one of the four obsidian sources in the central-western Mediterranean, is one of the islets that dot the region.

A)

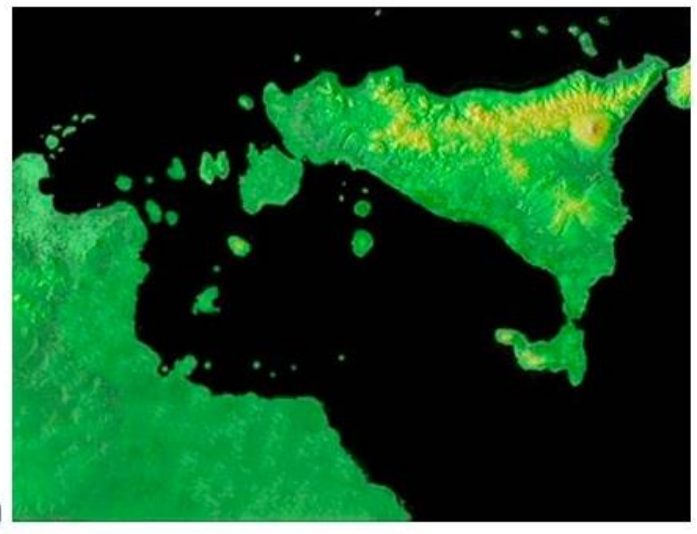

B)

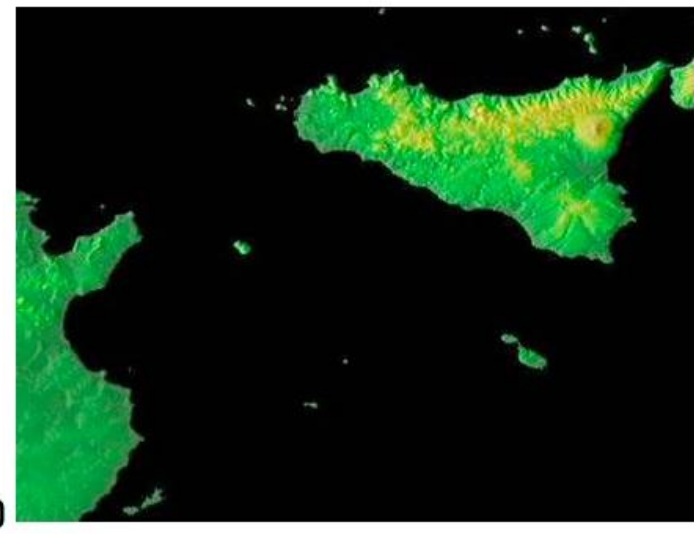

Figure 8. A) The Strait of Sicily at the time of MWP 1a (Rapisarda 2008) [52]; B) The Strait of Sicily today.

The Strait of Sicily divides Sicily from the Atlas Mountains, a chain in northern Maghreb situated at about the same latitude as southern Anatolia. Twelve thousand years ago the plains situated south of the mountain chain in today's Tunisia and Algeria were not arid $(41,42,30)$ as they are today. A large river flowed among them and the overall climatic situation might have been similar to that of the Near East. 
Although the Maghreb has not yet been exhaustively investigated [76] it is known that it has been inhabited since the early Palaeolithic. It is also apparent that the end of Younger Dryas marked the transition from the Upper Palaeolithic to the Epipalaeolithic in the region [77]. Iberomaurusian, the characteristic technology present in the Maghreb between about twenty thousand and ten thousand years ago [78], was followed in Tunisia and Algeria by the Capsian, a culture marked by a visible change in customs and habits, albeit remaining a hunter-gatherer Epipalaeolithic one [79]. The Capsians showed a particular dietary propensity for land snails [80], testified to by the presence of thousands of escargotières (artificial mounds made up of snail shells), whose size and locations near springs or passes indicate a prevalently sedentary population. This penchant for such a delicacy of French cuisine is indeed a mark of a superior civilization, but it is doubtful that escargots per se can be taken as proof of a Neolithic transition and a more pregnant sign should be sought.

Meanwhile, across the Strait, Sicily too was in the late Palaeolithic. On the island the concentration of Palaeolithic remains is mainly western [81, p. 23] and different from that of the mostly eastern Neolithic ones, [81, p. 53], suggesting that its former colonizers might have come from North Africa.

The presence of settlements on the two shores of the Strait and the hypothesis of an early African colonization of Sicily hint therefore at an occupation of the then existing archipelago, because some safe harbours along the route would have been an important aid to maritime travel.

Apart from Pantelleria itself, where might we find traces of such ancient occupation in the Strait of Sicily, or, in other words, which isobath (or sea level) should indicate the shores of twelve thousand years ago? E. Bard, Hamelin, and Fairbanks [37] estimated that before MWP $1 \mathrm{~b}$ the oceans' level was about sixty metres below today's. Lambeck et al. [82], through a geological model developed for Italy, later concluded that the same level was also valid for the Mediterranean Sea. ${ }^{10}$ Still, Lambeck, like Ferranti et al. [84], considered likely a marked subsidence of the southern border of Sicily, a factor that would add about a dozen metres to the eustatic value of the seabed near the southern coast of Sicily (leading the value of the isobath to choose there to around -70 metres).

Taken with a grain of salt, Fig. 8 A) depicts a profile not very different from what might have been the Strait of Sicily during the Younger Dryas, showing an intriguing feature which would remain even if slightly different sea levels were selected. This feature is the presence of an archipelago, which would have permitted navigation between Tunisia and Sicily with land always in sight. An archipelago that a ten or twenty-metre rise in sea level would have modified, but not entirely submerged.

Occupying the maritime link between two continents would have been an advantage in a period that saw navigation progress rapidly. As we saw, in the Aegean Sea regular routes were being established to supply Melos obsidian to the mainland and, in the middle of the Strait of Sicily, there was an obsidian source in Pantelleria. It is unlikely that those living in the proximity would not have noticed it.

Between fourteen and eleven thousand years ago the region underwent significant changes. In the south western corner of Sicily, the large shallow seabed named Avventura bank (Fig. 9) was a peninsula (Fig. 8 A) before MWP 1a and later a group of islands. In front of it, Tunisia stretched into the sea with a large floodplain that included the island of Lampedusa. Portions of these plains survived the sea level rise of MWP 1a and experienced the warming of the Bølling-Allerød period.

\footnotetext{
${ }^{10}$ Recently, Lambeck et al. (2014) [83], summarizing a large number of measurements carried out in the Indian and Pacific Oceans, confirmed that the sea level variation due to eustatic factor, with respect to twelve thousand years ago, should be about sixty metres.
} 


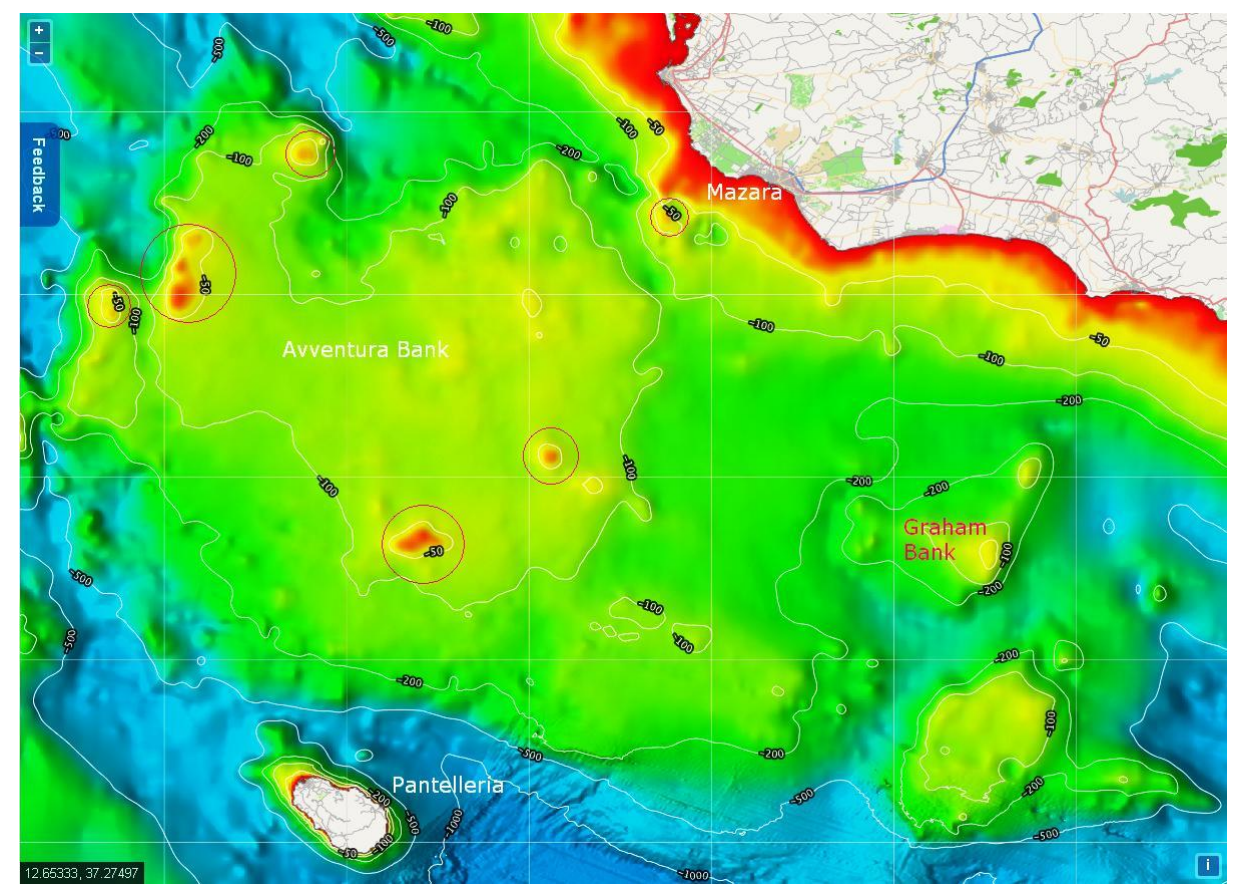

Figure 9. The bathymetry of Avventura and Graham banks. In the red circles, six seafloors which were islands at the end of the Younger Dryas and had to face the upheaval of MWP $1 \mathrm{~b}$ (map from EMODnet 2015) [85].

A few millennia later, at the end of the Younger Dryas (when the sea level was about fifty metres lower than today) the geographical situation had changed considerably (Fig. 10): most of the Avventura bank had been submerged, but an archipelago was still there to ensure a safe route to Pantelleria's obsidian. If the region was inhabited it is likely that its most convenient spots were too, like the island closing a small southbound gulf near Mazara, or some of the islets on the route to Pantelleria.

The Avventura bank is partly surrounded by volcanoes, whose coastline history is too complex to reconstruct, since they have been subject to their own geological movements. It is interesting to note one of them: Graham bank, a submarine volcano located about thirty miles south of Sciacca. Most of the time it was entirely submerged, but during its occasional eruptions it may have managed to emerge (to become Graham Island or Isola Ferdinandea as happened in 1831).

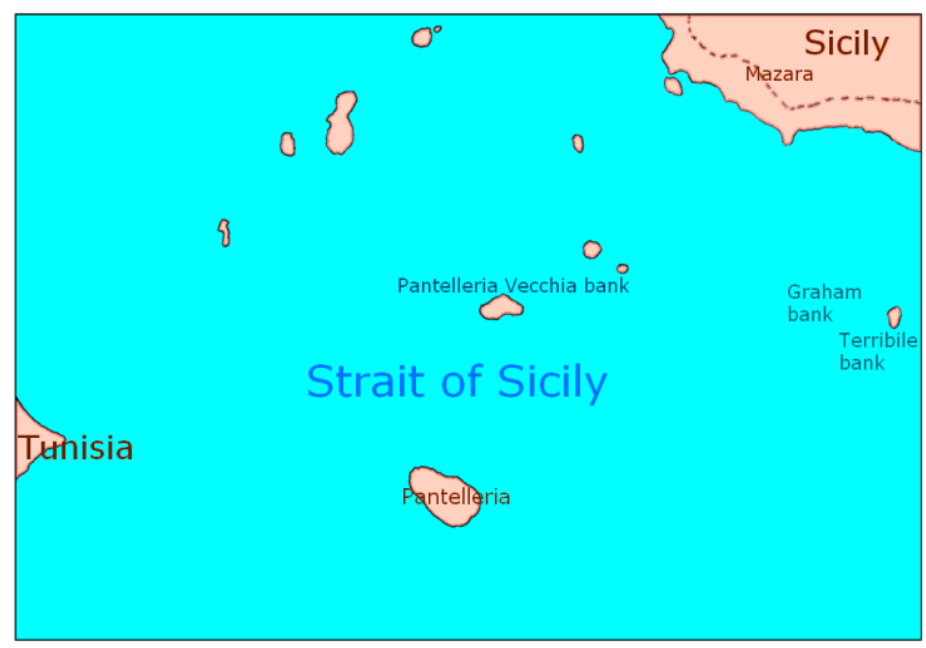

Figure 10. Map of the Strait of Sicily obtained from the $-50 \mathrm{~m}$ isobath provided by EMODnet [85]. The dotted line indicates the present Sicilian shoreline; note the small island closing a small gulf near Mazara and the larger one (Pantelleria Vecchia) on the route from there to Pantelleria.

Graham bank (Fig. 9) is one of the summit cones of a much larger submarine volcanic building, named Empedocles, located at $37^{\circ} 10^{\prime} \mathrm{N}, 12^{\circ} 43^{\prime} \mathrm{E}$ (of which the Terribile bank is another cone, for 
the moment quiet, see Fig. 10). In fact, the Strait of Sicily is dotted with volcanoes, submarine and otherwise (Pantelleria and Linosa are the two emerged examples). Needless to say, an explosive eruption from any of them, possibly accompanied by an earthquake and a tsunami, would have been a dramatic way to end human occupation in the region.

\section{Obsidian as a possible clue in the central Mediterranean basin}

To check whether the Strait of Sicily was really inhabited at the end of the Younger Dryas, obsidian could prove straightforward: given its uniqueness, finding some on a submerged seabed would demonstrate the seabed's occupation at the time of its emersion.

Obsidian is a volcanic glass formed by the sudden cooling of lava rich in silicon. The possibility to chip it and create sharp edges, its hardness and its shine made it a material suitable for crafting tools, weapons and jewellery, turning it in one of the most wanted assets of the prehistoric age. Its macroscopic characteristics (colour, homogeneity, hardness) and its chemical composition [86] are typical of each specific lava flow, making it possible to establish the geographical origin of obsidian artefacts found in sites far from their source.

Few volcanoes produce obsidian, because the conditions for its formation are rather uncommon. Since 1970 it has been known that only four islands (Sardinia, Palmarola, Lipari and Pantelleria) provided all the obsidian found in the western Mediterranean [87].

Although the first use of obsidian dates back to one hundred thousand years ago in the Horn of Africa [88], in the Mediterranean basin its utilization is normally associated with Neolithic culture. In the Western Mediterranean, the accepted chronology states that its systematic exploitation began about eight thousand years ago [89]. In Sicily the use of obsidian is associated with the spread of Neolithic culture and agriculture in the region [90], a thesis also corroborated by recent excavations [91, 92], which confirmed the absence of obsidian in Palaeo/Mesolithic layers. The Neolithic association is also assumed valid on the other side of the Strait: the date of $8000 \mathrm{BP}$ for the first use of obsidian is, for example, confirmed in Tunisia, by preliminary research undertaken by Mulazzani et al. [93].

This general depiction seems not to leave much hope of finding pre-Neolithic specimens in the region. However, looking more closely, some odd details emerge. Naturally, the distance from the two Sicilian sources determined their geographic penetration. The island was basically divided into two market basins: the north-eastern one served by Lipari and the south-western by Pantelleria, but the supply changed with time. In some sites situated along the hypothetical border dividing the basins, both islands provided the obsidian: in the village of Mandria di Serra del Palco (Caltanissetta), which was continuously inhabited during prehistory, the percentage of Pantellerian material fell progressively during the Neolithic period in comparison to that from Lipari [94]. A similar replacement of supply source happened in Cava dell'Uzzo (Trapani) [91] and at Skorba (Malta) (p. 67) [95].

The timeline of the diffusion and the change in supply appear somewhat peculiar. Although the mineral had been always available in Pantelleria but not in Lipari (Lipari's oldest flow dates back to eight or nine thousand years ago [96]), it seems that nobody collected it before the Lipari eruption advertised the precious material. It is therefore to be understood why many ran initially to Pantelleria to collect it, although the version from Lipari, glassier and shinier, was always the favourite. As a matter of fact, later Lipari progressively became the only source for most sites.

A linear explanation could be that the exploitation actually started before the Neolithic era. This idea was initially suggested about twenty years ago by the discovery of some artefacts in Mesolithic layers (unfortunately in the presence of disturbed stratigraphy) and of a Liparian blade, found at Perriere Sottano (Catania) and dated $9500 \mathrm{BP}$ cal. [97]. It gained some strength when two other obsidian blades, dated between 9500 and 9800 BP cal., were later discovered at Favignana (Trapani) [98]. But it was the recent discovery of a pre-Neolithic processing site near Punta Tracino (Pantelleria) at an underwater depth of about twenty metres [99] which showed that the hypothesis is not entirely far-fetched. 
The hope of finding obsidian processing residues on a submerged seabed is helped by another peculiarity of Pantelleria. The island shows no traces of human settlements at the time of its Neolithic exploitation and the remains of its lithic industry are far more modest than those of Lipari (p. 73) [81], which instead became inhabited and acquired importance essentially due to its obsidian industries. Quite paradoxically, the first known traces of stable communities in Pantelleria date back to five thousand years ago, when collection of obsidian from the island was already very scant.

The absence of settlements contemporary to the obsidian exploitation period is usually explained by the intense agricultural terracing experienced by Pantelleria over the centuries, which would have erased the traces of the ancient sites (although it is yet to be understood why the terracing process did not erase more recent remains). However, the particularity of the island, barely cultivable and lacking beaches or a safe port, could itself justify the absence of stable settlements and the choice of a collection method that did not require operations on site. If so, the first recorded inhabitants may have only settled when the obsidian gatherers ceased to raid the island. If this is the context, the pre-Neolithic processing site on the seafloor of Punta Tracino could indicate a former occupation of its shores (now submerged) followed by an early Neolithic abandonment of the island, perhaps due to the vanishing of the archipelago that facilitated navigation to the mainland.

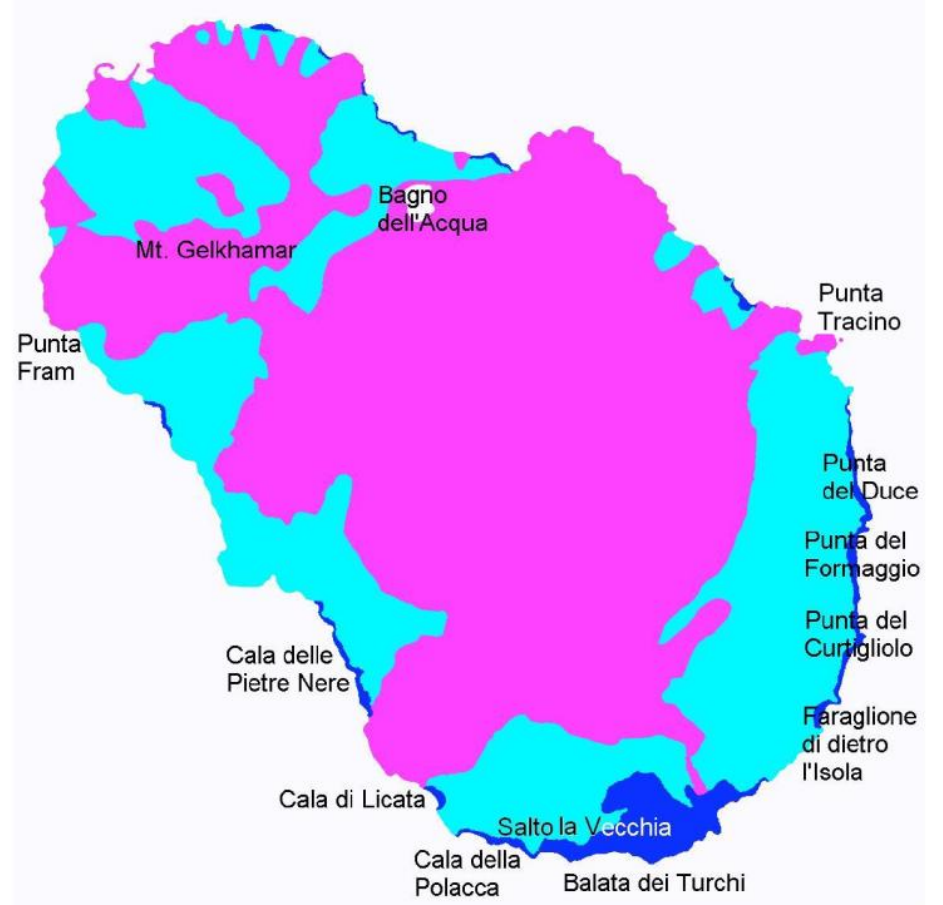

Figure 11. Schematic map of the eruptions pre and post green tuff, from Rapisarda [100], based on the Pantelleria geological map of Orsi [101]. The flow of green tuff is shown in turquoise, while magenta indicates the surface affected by all successive lava flows. The areas in blue are the coastal zones where the layers prior to green tuff are accessible because the sea erosion that created the cliffs tore the cover.

To illustrate a possible way of gathering obsidian without landing on the island it is helpful to summarize its orographic characteristics. Pantelleria's geological history is marked by the Green Tuff eruption that almost completely covered it about forty-five thousand years ago [102]. Five obsidian flows have been identified: three almost horizontal layers at Balata dei Turchi and two deposits at Bagno dell'Acqua and Gelkhamar [103]. The Gelkhamar source looks similar to the lava flows of the island of Lipari, NE of Sicily; the deposit at Bagno dell'Acqua is fragmented and scarce; but the conformation of the three lava flows at Balata dei Turchi is rather peculiar, although consistent with the orography of the southern part of the island [100]. Because of the limited slopes 
and the absence of pronounced valleys, the southern part of the island is characterized by lava flows that extend almost uniformly around the volcanic cone. The obsidian flows most exploited for the manufacture of prehistoric objects were the southern ones, from Salto la Vecchia to Balata dei Turchi (Fig. 11). This prevalence, well known among the Sicilian finds [89], has been confirmed in Tunisia too [93].

The landslide at Cala delle Pietre Nere (Scauri), which dragged obsidian blocks from the above vein into the sea, suggests a practical method of collecting the mineral from the southern flows: skirting the shore with a boat and picking up what you need (Fig. 12). This does not require docking on the island - dangerous almost everywhere - or climbing the cliffs (even more hazardous). The method favours the collection of the raw material as it is, leaving the refining process for later, on the way back or once returned home. Such a collection method could easily explain the deficiency of industries for processing the mineral on the island.
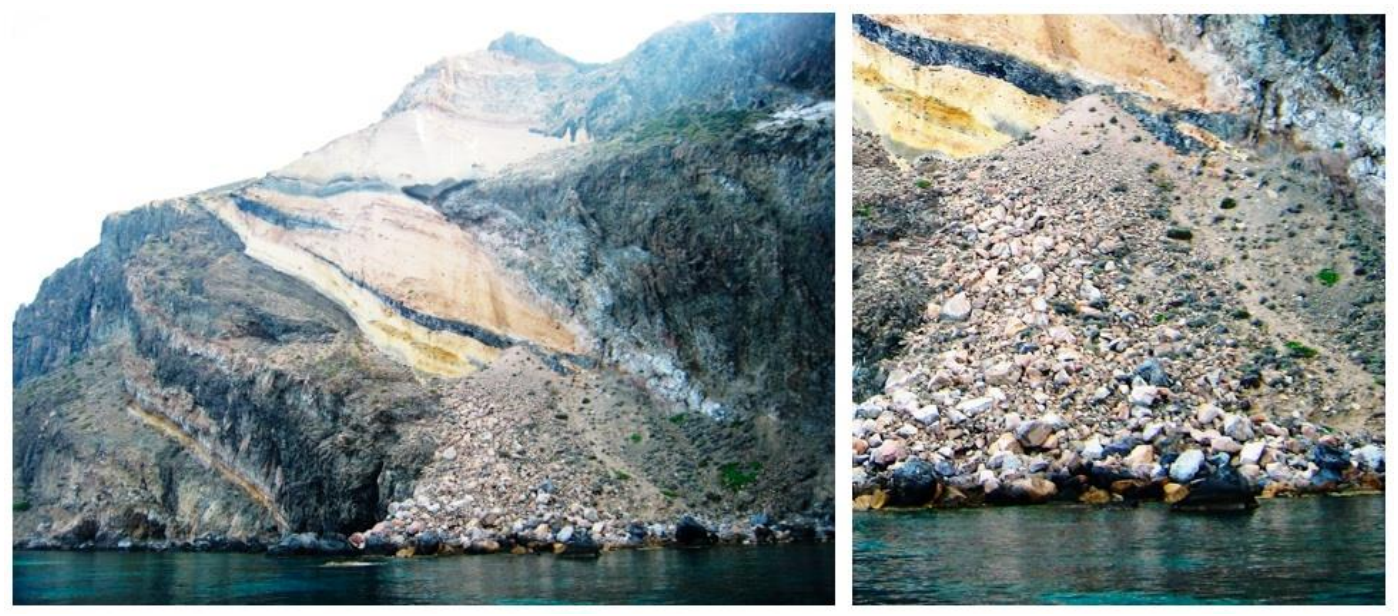

Figure 12. Cala delle Pietre Nere, near Scauri (enlarged detail on the photo to the right). In the cliff (about 150 metres high) the obsidian flows are clearly visible, inserted between layers of yellowish pumice. The landslide, containing large blocks of obsidian, is partially emerged and partially submerged. In these conditions, the collection of material from the sea does not require landing on the island (rather difficult everywhere) but simply approaching the landslide with a boat and helping oneself.

If the obsidian was not treated locally due to the difficulties docking on the island, it might have been processed on a handy site along the route home. If exploitation was already active during the Younger Dryas, the islets that then emerged along the route to Sicily (Pantelleria Vecchia bank, for example) could have been a convenient place to do this job (Fig. 10). The remnants of an obsidian industry, if found there, would constitute irrefutable proof of human presence at the end of the Younger Dryas. Given that, as mentioned, a rather similar discovery has recently been made on the seafloor of Pantelleria [99], the same kind of research at some selected spots on the Avventura bank at -20 and -40 should not be unthinkable.

\section{Discussion}

The climatic upheavals and the technological revolutions that occurred eleven thousand five hundred years ago in some areas of the Mediterranean basin, combined with the timing of the alleged destruction of Plato's Atlantis, raise the possibility that the legend may have drawn inspiration from these events, passed down through Egyptian mythology. The changes in climate concerned the whole northern hemisphere and several Mediterranean areas, including the Nile delta, could have hosted an early Neolithic society sharing some of the innovations recorded in the Near East, whose traces would have been later erased by the rise in sea level.

Thanks to its geographical position, the archipelago that then lay in the Strait of Sicily experienced the same climatic change endured by the Near East. The traces of an early occupation of the region are admittedly weak, consisting of the recent discoveries of an underwater 
pre-Neolithic processing site at Pantelleria and a few obsidian blades scattered in Sicily. Nevertheless, they support the possibility of finding similar traces (for example the remnants of an obsidian industry) on the seafloors that were emerged twelve thousand years ago, a discovery that would prove beyond doubt that the Strait was inhabited at the end of the Younger Dryas.

Obviously, such a discovery would not demonstrate that such proto-Neolithic settlement actually inspired the myth of Atlantis, but it would show that the Strait of Sicily was inhabited much earlier than is believed today, which would represent a considerable archaeological result in itself. All in all, there may have been more than one "Atlantis" in the Mediterranean and beyond: although historically their existence may never be proved, from a geological and environmental perspective, their presence is a strong possibility. Such prehistoric "Atlantises" could never have been as advanced as the one described by Plato, but could well have contained the seeds that inspired the myth.

Conflicts of Interest: The author declares no conflict of interest.

\section{Appendix A}

Both Plato and Diodorus gave geographical indications regarding the location of Atlantis.

Since Plato's indications were not relevant to his propaganda issues, one could imagine that the geographical details of the dialogues maintained some unmodified elements of the original Egyptian myth. Questionable as this is, a summary of Plato's main clues is reported below.

Nine thousand years before the visit of Solon to Sais (Tim. III 23.e; Crit. III 108.e), the Atlantic Sea ${ }^{11}$ was navigable (Crit. III 109.a) and, in front of the Pillars of Hercules (Tim. III 24.e), was an island larger than Libya and Asia combined. This island was close to other islands and, by 'hopping' between them, one could reach the continent that enclosed the vast ocean. The 'capital' of this empire was a small island which ruled over the entire archipelago. On the continent, Atlantis ruled Europe up to Thyrrenia and Libya (Africa) from the Pillars to the Egyptian border (Tim. III 25.b). The main island of the archipelago had a large plain, three thousand stadia (approximately, $550 \mathrm{~km}$ ) long and two thousand stadia $(350 \mathrm{~km})$ wide, ${ }^{12}$ surrounded by northern mountains and by a southern channel that ended in the open sea (Crit. X 118.b), with rivers, lakes, mountains and marshes, two harvests per year (Crit. X 118.e), elephants (Crit. VI 114.e) and exotic fruits (Crit. VI 115.b). Its first king was Atlas (Crit. VI 114.b), who ran the country perfectly, following commendable political principles, second only to those of Athens. But when Atlantis wanted to conquer Egypt and Athens, the heroic Athenians resisted and defeated it, freeing Egypt, which in the meantime had been subjugated, as well. A little later, a violent earthquake and a flood destroyed Atlantis in a day and a night, leaving an impenetrable swamp in place of the island (Tim. III 26.d); Athens also perished in the cataclysm.

Diodorus too provided some geographical hints about Atlantis. According to him many generations before the Trojan War, the refined Atlanteans were subjugated by the Libyan Amazons (Book III, 54, 1). In fact, long before the Amazons of classical tradition (who lived along the river Thermodon, on the southern coast of the Black Sea - author's note), Libya was inhabited by other

\footnotetext{
11 Plato uses the term Atlantic Sea indistinguishably for an enclosed sea near the island-capital (no longer delimited in Plato's times due to the sinking of the islands that used to surround it and no longer navigable due to the presence of marshes and shallow waters) and for a large open sea, surrounded by the continent dominated by Atlantis.

12 The dimensions of the plain of Atlantis are not those of a continent, in contradiction of the statement "Libya and Asia combined", whose size Plato was certainly aware of. To this extent one point should be clear: twelve thousand years ago (or even at the glacial maximum) in no part of the world was there an emerged seabed the size of a continent. The bottom of the Atlantic Ocean is thousands of metres deep and no portion of it ever emerged following a drop in sea level of just 120 metres. From a geological point of view, twelve thousand years is a pittance, ten thousand times shorter than the movements of continental plates. Those invoking the continental drift demand movements occurring over tens or hundreds of millions of years, not thousands of years: days when humans simply did not exist.
} 
Amazons originating from an island on Lake Tritonis ${ }^{13}$ (Book III, 53, 4), from which they dominated the surrounding region (Figure A1). ${ }^{14}$

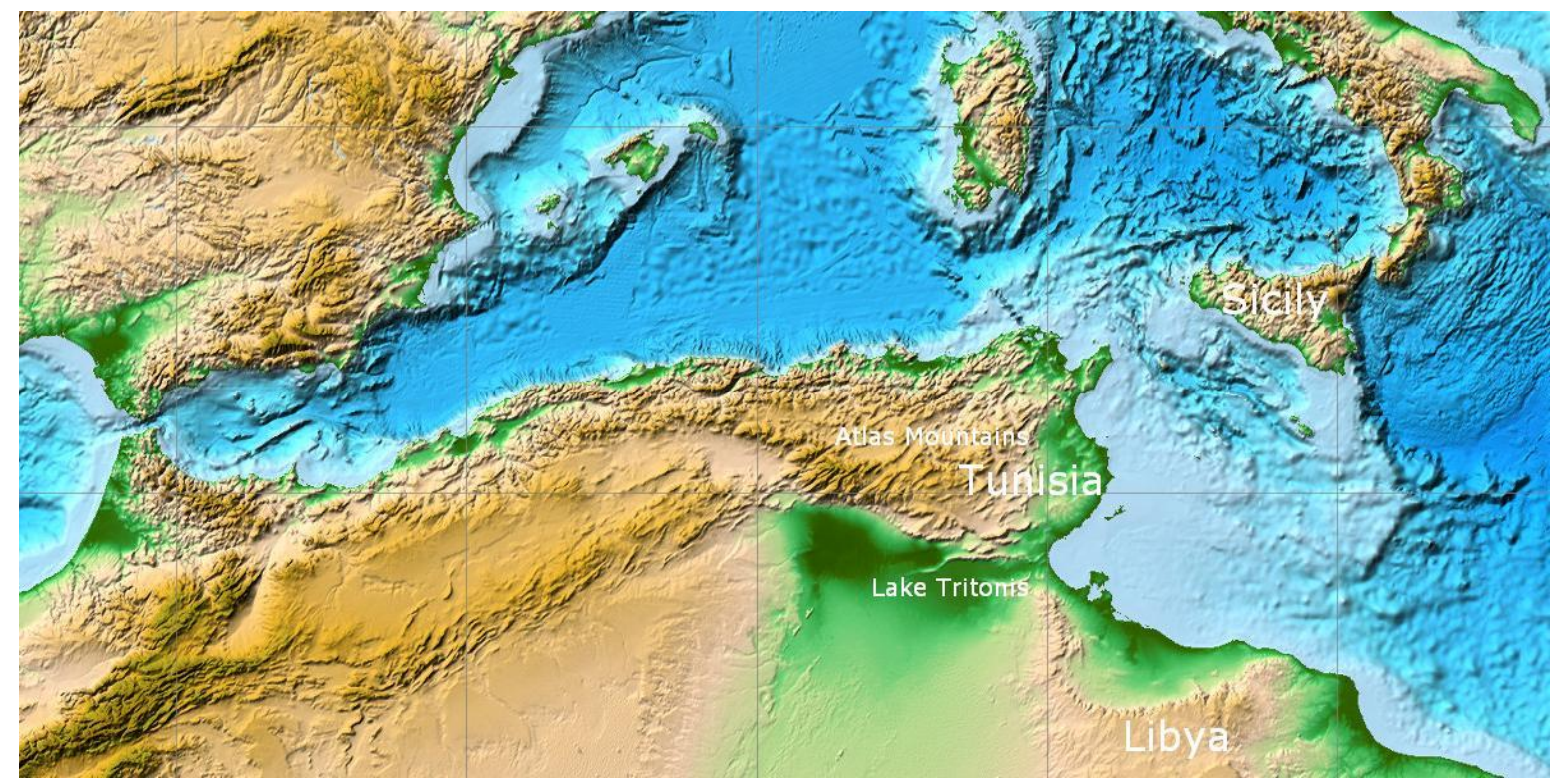

Figure A1. The locations the Atlanteans, according to Diodorus. Map from NOAA site. ${ }^{15}$

The Atlanteans surrendered en masse to the Amazon queen Myrina when Cernê, the only city of theirs that had tried to resist, was completely destroyed (Book III, 54, 5). According to Diodorus, the Atlanteans, who had many cities and lived in a fertile region on the coast (Book III, 56, 2), were an extremely refined and pious people, because the gods had been born among them. Their first king had been Uranus, a god who had elevated them from their bestial state and taught them agriculture (Book III, 56, 3).

Uranus had several wives, including Titea, later called Gaea, who bore him eighteen children: the Titans. One of these, Hyperion, succeeded his father and, on his death, the kingdom was divided between his brother Kronos and his nephew Atlas (son of another brother, Iapetus). Atlas took the coastal and the mountainous regions, giving his name not only to the mountains, but also to the inhabitants of the whole kingdom (Book III, 60, 1). According to the Cretans, Kronos reigned over Sicily, Libya and Italy (Book III, 60, 3).

\section{References}

1. Plato Plato in Twelve Volumes. Vol. 9, translated by W. R. M. Lamb. The Loeb Classical Library. Cambridge, Mass.: Harvard University Press, William Heinemann Ltd. London, 1925. Available online at Perseus Digital Library: http://catalog.perseus.org/catalog/urn:cts:greekLit:tlg0059.

2. Taylor, A. E. Plato The Man and His Work; Methuen \& Co. Ltd., London, 1926. ISBN 0-486-41605-4.

3. Herodotus The history of Herodotus. Trans. by G. C. Macaulay 2 vols. Macmillan, London, 1890. Online translations at Project Gutenberg: Vol. 1, Vol. 2.

4. Rapisarda, M. A scientific approach to Plato's Atlantis. Atti della Accademia Peloritana dei Pericolanti. Classe di Scienze Fisiche, Matematiche e Naturali, 93 (2), C1 [58 pages], 2015; DOI: 10.1478/AAPP.932C1.

5. Van De Mieroop, M. A History of Ancient Egypt; John Wiley \& Sons 2011. ISBN 978-1-4051-6070-4.

\footnotetext{
${ }^{13}$ Identifiable with the vast Saharan depression south of the Atlas Mountains, which was actually a lake several thousand years ago.

14 The source, quoted by Diodorus, is Dionysius, almost certainly Scytobrachion, a Mytilene mythographer who lived and taught in Alexandria in the second century BC.

${ }^{15}$ http://maps.ngdc.noaa.gov/viewers/wcs-client/
} 
6. Pausanias Description of Greece with an English Translation by W. H. S. Jones and H. A. Ormerod, 4 vols.: Harvard University Press, Cambridge, Mass. 1918. Available online at Perseus Digital Library: http://www.perseus.tufts.edu/hopper/text?doc=Perseus\%3Atext\%3A1999.01.0160.

7. Diodorus of Sicily The Library of History. II. Trans. by C. H. Oldfather. 12 vols. The Loeb Classical Library 303. Harvard University Press, Cambridge, Mass. 1935.

URL: http://www.loebclassics.com/view/LCL303/1935/pb LCL303.i.xml.

8. Sergent, B. L'Atlantide et la mythologie grecque, L'Harmattan, Paris, 2006. ISBN 978-2296010109.

9. EPICA community members. Augustin, L., Barbante, C., Barnes, P. R. F., Marc Barnola, J., Bigler, M., Castellano, E., Cattani, O., Chappellaz, J., Dahl-Jensen, D., Delmonte, B., Dreyfus, G., Durand, G., Falourd, S., Fischer, H., Fluckiger, J., Hansson, M. E., Huybrechts, P., Jugie, G., Johnsen, S. J., Jouzel, J., Kaufmann, P., Kipfstuhl, J., Lambert, F., Lipenkov, V. Y., Littot, G. C., Longinelli, A., Lorrain, R., Maggi, V., Masson-Delmotte, V., Miller, H., Mulvaney, R., Oerlemans, J., Oerter, H., Orombelli, G., Parrenin, F., Peel, D. A., Petit, J.-R., Raynaud, D., Ritz, C., Ruth, U., Schwander, J., Siegenthaler, U., Souchez, R., Stauffer, B., Peder Steffensen, J., Stenni, B., Stocker, T. F., Tabacco, I. E., Udisti, R., Wal, R. S. W. van de, Broeke, M. van den, Weiss, J., Wilhelms, F., Winther, J. G., Wolff, E. W., and Zucchelli, M. Eight glacial cycles from an Antarctic ice core. Nature 2004, 429(6992), 623-628. DOI: 10.1038/nature02599.

10. Clark, P. U., Dyke, A. S., Shakun, J. D., Carlson, A. E., Clark, J., Wohlfarth, B., Mitrovica, J. X., Hostetler, S. W., and McCabe, A. M. The last glacial maximum. Science 2009, 325(5941), 710-714. DOI: 10.1126/science.1172873.

11. Broodbank, C. The origins and early development of Mediterranean maritime activity. Journal of Mediterranean Archaeology 2006, 19 (2), pp. 199-230. DOI: 10.1558//jmea.2006.v19i2.199.

12. Cleyet-Merle, J. J. La préhistoire de la pêche. Collection des hespérides. Ed. Errance, Paris, 1990.

13. Alley, R. B. The Younger Dryas cold interval as viewed from central Greenland. Quaternary Science Reviews 2000, 19(1), 213-226. DOI: 10.1016/S0277-3791(99)00062-1.

14. Ammerman, A. J., Flourentzos, P., McCartney, C., Noller, J. S., and Sorabji, D. Two new early sites on Cyprus. Report. Cyprus: Department of Antiquities, 2006, pp. 1-22.

15. Renfrew, C. and Aspinall, A. Aegean obsidian and Franchthi cave. In: Les industries lithiques taillées de Franchthi (Argolide, Grèce). Les industries du mésolithique et du néolithique initial. Ed. by C. Perlès. Vol. 2. Excavations at Franchthi Cave, Greece. Indiana University Press, Bloomington, Indiana (USA) 1990, pp. 257-270.

16. Dmaps.com, available online: http://www.d-maps.com/carte.php?num car=3161\&lang=it.

17. Dietrich, O., Köksal-Schmidt, C., Notroff, J., and Schmidt, K. Establishing a radiocarbon sequence for Göbekli Tepe. State of research and new data. Neo-Lithics. The Newsletter of Southwest Asian Neolithic Research 2013, (1/13), 36-41.

18. Purugganan, M. D. and Fuller, D. Q. The nature of selection during plant domestication. Nature 2009, 457(7231), 843-848. DOI: 10.1038/nature07895.

19. Kislev, M. E., Nadel, D. and Carmi, I. Epipalaeolithic (19,000 BP) cereal and fruit diet at Ohalo II, Sea of Galilee, Israel. Review of Palaeobotany and Palynology 1992, 73(1), 161-166.

DOI: 10.1016/0034-6667(92)90054-K.

20. Bar-Yosef, O. The Natufian culture in the Levant, threshold to the origins of agriculture. Evolutionary Anthropology: Issues, News, and Reviews 1998, 6(5), 159-177.

URL: http://dx.doi.org/10.1002/(SICI)1520-6505(1998)6:5\%3C159::AID-EVAN4\%3E3.0.CO;2-7.

21. Bar-Yosef Mayer, D. E. and Porat, N. Green stone beads at the dawn of agriculture. Proceedings of the National Academy of Sciences 2008, 105(25), 8548-8551. DOI: 10.1073/pnas.0709931105.

22. Arranz-Otaegui, A., Carretero, L. G., Ramsey, M. N., Fuller, D. Q., Richter, T. "Archaeobotanical evidence reveals the origins of bread 14,400 years ago in northeastern Jordan," PNAS (2018). www.pnas.org/cgi/doi/10.1073/pnas.1801071115

23. Siddall, M., Rohling, E. J., Almogi-Labin, A., Hemleben, C., Meischner, D., Schmelzer, I., and Smeed, D. A. Sea-level fluctuations during the last glacial cycle. Nature 2003, 423(6942), 853-858. DOI: 10.1038/nature01690.

24. Bailey, G. N. and Flemming, N. C. Archaeology of the continental shelf: marine resources, submerged landscapes and underwater archaeology. Quaternary Science Reviews 2008, 27(23), 2153- 2165. DOI: 10.1016/j.quascirev.2008.08.012. 
25. Munro, N. D. Small game, the Younger Dryas, and the transition to agriculture in the southern Levant. Mitteilungen der Gesellschaft für Urgeschichte 2003, 12(4), 47-71.

26. Lambeck, K., Esat, T. M., and Potter, E.-K. Links between climate and sea levels for the past three million years. Nature 2002, 419(6903), 199-206. DOI: 10.1038/nature01089.

27. North Greenland Ice Core Project members: Andersen, K. K., Azuma, N., Barnola, J. M., Bigler, M., Biscaye, P., Caillon, N., Chappellaz, J., Clausen, H. B., Dahl-Jensen, D., Fischer, H., Flückiger, J., Fritzsche, D., Fujii, Y., Goto-Azuma, K., Grønvold, K., Gundestrup, N. S., Hansson, M., Huber, C., Hvidberg, C. S., Johnsen, S. J., Jonsell, U., Jouzel, J., Kipfstuhl, S., Landais, A., Leuenberger, M., Lorrain, R., Masson-Delmotte, V., Miller, H., Motoyama, H., Narita, H., Popp, T., Rasmussen, S. O., Raynaud, D., Rothlisberger, R., Ruth, U., Samyn, D., Schwander, J., Shoji, H., Siggard-Andersen, M. L., Steffensen, J. P., Stocker, T., Sveinbjörnsdóttir, A. E., Svensson, A., Takata, M., Tison, J. L., Thorsteinsson, T., Watanabe, O., Wilhelms, F. and White, J. W. C. High-resolution record of Northern Hemisphere climate extending into the last interglacial period. Nature 2004, 431(7005), 147-151. DOI: 10.1038/nature02805.

28. EPICA community members: Barbante, C., Barnola, J. M., Becagli, S., Beer, J., Bigler, M., Boutron, C., Blunier, T., Castellano, E., Cattani, O., Chappellaz, J., Dahl-Jensen, D., Debret, M., Delmonte, B., Dick, D., Falourd, S., Faria, S., Federer, U., Fischer, H., Freitag, J., Frenzel, A., Fritzsche, D., Fundel, F., Gabrielli, P., Gaspari, V., Gersonde, R., Graf, W., Grigoriev, D., Hamann, I., Hansson, M., Hoffmann, G., Hutterli, M. A., Huybrechts, P., Isaksson, E., Johnsen, S., Jouzel, J., Kaczmarska, M., Karlin, T., Kaufmann, P., Kipfstuhl, S., Kohno, M., Lambert, F., Lambrecht, A., Lambrecht, A., Landais, A., Lawer, G., Leuenberger, M., Littot, G., Loulergue, L., Lüthi, D., Maggi, V., Marino, F., Masson-Delmotte, V., Meyer, H., Miller, H., Mulvaney, R., Narcisi, B., Oerlemans, J., Oerter, H., Parrenin, F., Petit, J. R., Raisbeck, G., Raynaud, D., Rothlisberger, R., Ruth, U., Rybak, O., Severi, M., Schmitt, J., Schwander, J., Siegenthaler, U., Siggaard-Andersen, M. L., Spahni, R., Steffensen, J. P., Stenni, B., Stocker, T. F., Tison, J. L., Traversi, R., Udisti, R., Valero-Delgado, F., Broeke, M. R. van den, Wal, R. S. W. van de, Wagenbach, D., Wegner, A., Weiler, K., Wilhelms, F., Winther, J. G. and Wolff, E. One-to-one coupling of glacial climate variability in Greenland and Antarctica. Nature 2006, 444(7116), 195-198. DOI: 10.1038/nature05301.

29. Williams, M., Dunkerley, D., De Decker, P., Kershaw, P., and Chappell, J. Quaternary environments. 2nd ed.; Arnold, London, 1998. ISBN 0-340-69151-4.

30. Gasse, F. Hydrological changes in the African tropics since the Last Glacial Maximum. Quaternary Science Reviews 2000, 19(1), 189-211. DOI: 10.1016/S0277-3791(99)00061-X.

31. Fleming, K. M. Glacial rebound and sea-level change: constraints on the Greenland ice sheet. Ph.D. thesis. Australian National University, Canberra, 2000.

32. Fleming, K., Johnston, P., Zwartz, D., Yokoyama, Y., Lambeck, K. and Chappell, J. Refining the eustatic sea-level curve since the Last Glacial Maximum using far- and intermediate-field sites. Earth and Planetary Science Letters 1998, 163(1), 327-342. DOI: 10.1016/S0012-821X(98)00198-8.

33. Milne, G. A., Long, A. J. and Bassett, S. E. Modelling Holocene relative sea-level observations from the Caribbean and South America. Quaternary Science Reviews 2005, 24(10-11), 1183-1202. DOI: doi:10.1016/j.quascirev.2004.10.005.

34. Fairbanks, R. G. A 17,000-year glacio-eustatic sea level record: influence of glacial melting rates on the Younger Dryas event and deep-ocean circulation. Nature 1989, 342(6250), 637-642. DOI: 10.1038/342637a0.

35. Bard, E., Hamelin, B., Fairbanks, R. G. and Zindler, A. Calibration of the $14 \mathrm{C}$ timescale over the past 30,000 years using mass spectrometric U-Th ages from Barbados corals. Nature 1990, 345, 405-410. DOI: 10.1038/345405a0.

36. Wang, Y. J., Cheng, H., Edwards, R. L., An, Z. S., Wu, J., Shen, C. C. and Dorale, J. A. A high-resolution absolute-dated late Pleistocene monsoon record from Hulu Cave, China. Science 2001, 294(5550), 2345-2348. DOI: 10.1126/science.1064618.

37. Bard, E., Hamelin, B., and Fairbanks, R. G. U-Th ages obtained by mass spectrometry in corals from Barbados: sea level during the past 130,000 years. Nature 1990, 346, 456-458. DOI: 10.1038/346456a0.

38. Liu, J. P. and Milliman, J. D. Reconsidering melt-water pulses 1A and 1B: Global impacts of rapid sea-level rise". Journal of Ocean University of China 2004, 3(2), 183-190. DOI: 10.1007/s11802- 004-0033-8.

39. Steffensen, J. P., Andersen, K. K., Bigler, M., Clausen, H. B., Dahl-Jensen, D., Fischer, H., Goto-Azuma, K., Hansson, M., Johnsen, S. J., Jouzel, J., Masson-Delmotte, V., Popp, T., Rasmussen, S. O., Röthlisberger, R., Ruth, U., Stauffer, B., Siggaard-Andersen, M.-L., Sveinbjörnsdóttir, Á. E., Svensson, A. and White, J. W. C. 
High-resolution Greenland ice core data show abrupt climate change happens in few years. Science 2008, 321(5889), 680-684. DOI: 10.1126/science.1157707.

40. GLOBE Task Team and others. Hastings, D. A., Dunbar, P. K., Elphingstone, G. M., Bootz, M., Murakami, H., Maruyama, H., Masaharu, H., Holland, P., Payne, J., Bryant, N. A., Logan, T. L., Muller, J.-P., Schreier, G. and MacDonald, J. S., eds. (1999). Global Land One-km Base Elevation Project. Version 1.0. National Oceanic and Atmospheric Administration, National Geophysical Data Center, 325 Broadway, Boulder, Colorado 80305-3328, U.S.A. URL: http://www.ngdc.noaa.gov/mgg/topo/globe.html (visited on 09/11/2015). Digital data base on the World Wide Web and CD-ROMs. Map displayed in Figs. 5 was exported from http://www.ngdc.noaa.gov/mgg/topo/pictures/GLOBALsealeveldrop110m.jpg.

41. Otto-Bliesner, B. L., Russell, J. M., Clark, P. U., Liu, Z., Overpeck, J. T., Konecky, B., deMenocal, P., Nicholson, S. E., He, F. and Lu, Z. Coherent changes of southeastern equatorial and northern African rainfall during the last deglaciation. Science 2014, 346(6214), 1223-1227. DOI: 10.1126/science.1259531.

42. Prentice, I. C., Jolly, D. and BIOME 6000 participants. Mid-Holocene and glacial-maximum vegetation geography of the northern continents and Africa. Journal of Biogeography 2000, 27(3), 507-519. DOI: 10.1046/j.1365-2699.2000.00425.x.

43. Cole, J. M., Goldstein, S. L., deMenocal, P. B., Hemming, S. R., Grousset, F. E. Contrasting compositions of Saharan dust in the eastern Atlantic Ocean during the last deglaciation and African Humid Period. Earth and Planetary Science Letters 2009, 278(3), 257-266. DOI: 10.1016/j.epsl.2008.12.011.

44. Bray, J. R. Pleistocene volcanism and glacial initiation. Science 1977, 197(4300), 251-254. DOI: 10.1126/science.197.4300.251.

45. Hall, K. Rapid deglaciation as an initiator of volcanic activity: An hypothesis. Earth Surface Processes and Landforms 1982, 7(1), 45-51. DOI: 10.1002/esp.3290070106.

46. Paterne, M., Guichard, F. and Labeyrie, J. Explosive activity of the South Italian volcanoes during the past 80,000 years as determined by marine tephrochronology. Journal of Volcanology and Geothermal Research 1988, 34(3-4), 153-172. DOI: 10.1016/0377-0273(88)90030-3.

47. Zielinski, G. A., Mayewski, P. A., Meeker, L. D., Whitlow, S., and Twickler, M. S. A 110,000-yr record of explosive volcanism from the GISP2 (Greenland) ice core. Quaternary Research 1996, 45(2), 109-118. DOI: 10.1006/qres.1996.0013.

48. McGuire, W. J., Howarth, R. J., Firth, C. R., Solow, A. R., Pullen, A. D., Saunders, S. J., Stewart, I. S. and Vita-Finzi, C. Correlation between rate of sea-level change and frequency of explosive volcanism in the Mediterranean. Nature 1997, 389(6650), 473-476. DOI: 10.1038/38998.

49. Mayewski, P. A., Meeker, L. D., Whitlow, S. 1., Twickler, M. S., Morrison, M. C., Bloomfield, P., Bond, G. C., Alley, R. B., Gow, A. J., Meese, D. A., Grootes, P. M., Ram, M., Taylor, K. C. and Wumkes, W. Changes in atmospheric circulation and ocean ice cover over the North Atlantic during the last 41,000 years. Science 1994, 263(5154), 1747-1751. DOI: 10.1126/science.263.5154.1747.

50. Hassan, F.A., Barich, B., Mahmoud, M., Hemdan, M.A.,. Holocene playa deposits of Farafra Oasis, Egypt, and their palaeoclimatic and geoarchaeological significance. Geoarchaeology 200116 (1), 29-46. DOI: 10.1002/1520-6548(200101)16:1<29::AID-GEA4>3.0.CO;2-O

51. Wendorf, F., Karlen, W., Schild, R. Middle Holocene environments of north and east Africa, with special emphasis on the African Sahara. In: Anderson, D.G., Maasch, K.A., Sandweiss, D.H. (Eds.), Climate Change and Cultural Dynamics: a Global Perspective on Mid-Holocene Transitions. 2007 Elsevier, New York, pp. 189-227. DOI: 10.1016/B978-012088390-5.50011-X

52. Kuper, R. and Kröpelin, S. Climate-controlled Holocene occupation in the Sahara: motor of Africa's evolution. Science 2006, 313(5788), 803-807. DOI: 10.1126/science.1130989.

53. Nicoll, K. Radiocarbon chronologies for prehistoric human occupation and hydroclimatic change in Egypt and northern Sudan. Geoarchaeology 2001, $16 \quad$ (1), 47-64. DOI: 10.1002/1520-6548(200101)16:13.0.CO;2-P.

54. Kuper, R. After 5000 BC: the Libyan desert in transition. Comptes Rendus Palevol 2006, 5 (1), 409-419. DOI: 10.1016/j.crpv.2005.10.013

55. Kröpelin, S., Verschuren, D., Lezine, A. M., Eggermont, H., Cocquyt, C., Francus, P., Cazet, J.-P., Fagot, M., Rumes, B., Russell, J.M., Darius, F., Conley, D.J., Schuster, M., Suchodoletz, H., Engstrom, D.R. Climate-driven ecosystem succession in the Sahara: the past 6000 Years. Science 2008, 320 (765), 765-768. DOI: 10.1126/science.1154913 
56. Kislev, M. E. Pre-domesticated cereal in the Pre-Pottery Neolithic A. People and Culture in Change, British Archaeological Reports International Series 508, ed Hershkovitz, I. 1989, (British Archaeological Reports, Oxford, UK), pp 147-151.

57. Colledge, S. Plant Exploitation on Epipalaeolithic and Early Neolithic Sites in the Levant, British Archaeological Reports International 2001, Series 986 (British Archaeological Reports, Oxford, UK).

58. Weiss, E., Kislev, M. E., Hartmann, A. Anthropology. Autonomous cultivation before domestication. Science 2006, 312 (5780): 1608-1610. DOI: 10.1126/science.1127235.

59. Lev-Yadun, S., Gopher, A., Abbo, S. Archaeology. The cradle of agriculture. Science 2000, 288 (5471): 1602-1603. DOI: 10.1126/science.288.5471.1602

60. Gopher, A., Abbo, S., Lev-Yadun, S. The 'when', the 'where' and the 'why' of the Neolithic Revolution in the Levant. Doc Praehist 2001, 28 : 49-62. DOI: 10.4312/dp.28.3.

61. Zohary, D., Hopf, M., Weiss, E. Domestication of Plants in the Old World. (Oxford Univ Press, Oxford, UK), 2012, 4th Ed. DOI: 10.1093/acprof:osobl/9780199549061.001.0001.

62. Arranz-Otaegui, A., Colledge, S., Zapata, L., Teira-Mayolini, L. C., Ibáñez J. J., Regional diversity on the timing for the initial appearance of cereal cultivation and domestication in southwest Asia. Proc Natl Acad Sci USA 2016 12; 113 (49): 14001-14006 DOI: 10.1073/pnas.1612797113.

63. Wendorf, F., Close, A. E., Schild, R., Wasylikowa, K., Housley, R. A., Harlan, J, R., Królik, H. Saharan exploitation of plants 8,000 years BP. Nature 1992, 359, 721-724. DOI: 10.1038/359721a0.

64. Hoffman, M. A. Egypt Before the Pharaohs. Dorset, New York 1979. ISBN-10: 0614216249.

65. Holmes, D. L. Rise of the Nile delta. Nature 1993, 363, 402-403. DOI: 10.1038/363402a0.

66. Gardiner, A. H. The Royal Canon of Turin. Oxford: printed for the Griffith Institute by the Oxford University Press, 1959.

67. Hsu, S. W. "The Palermo Stone: the earliest royal inscription from Ancient Egypt". Altorientalische Forschungen 2010, 37(1), 68-89. DOI: 10.1524/aofo.2010.0006.

68. Wilkinson, T. A. H. Royal annals of ancient Egypt. The Palermo Stone and its associated fragments. Studies in Egyptology. London and New York 2000: Kegan Paul International. ISBN-10: 0710306679.

69. Wengrow, D. The Archaeology of Early Egypt: Social Transformations in North-East Africa, c. 10,000 to 2,650 BC. Cambridge University Press. 2006 p. 21. ISBN 0521543746, 9780521543743.

70. Butzer, K. W. Early Hydraulic Civilization in Egypt. Univ. of Chicago Press, Chicago 1976. ISBN: 0-226-08634-8

71. Stanley, D. J. \& Warne A. G. Sea level and initiation of Predynastic culture in the Nile delta. Nature 1993 363 435-438. DOI: 10.1038/363435a0.

72. Zeder, M. A. Domestication and early agriculture in the Mediterranean Basin: origins, diffusion, and impact. Proceedings of the National Academy of Sciences 2008, 105 (33), 11597-11604. DOI: 10.1073/pnas.0801317105.

73. Zhao, Z. J. The Middle Yangtze region in China is one place where rice was domesticated: Phytolith evidence from the Diaotonghuan cave, northern Jiangxi. Antiquity, 1998, 72, 887-897. DOI:10.1017/S0003598X00087524.

74. Gupta, A. K. Origin of agriculture and domestication of plants and animals linked to early Holocene climate amelioration. Current Science, 2004, Vol. 87, No. 1, 54-59. URL: http://www.currentscience.ac.in/Downloads/download_pdf.php?titleid=id_087_01_0054_0059_0.

75. Rapisarda, M. The hypothesis of an Ice Age settlement in the Straits of Sicily". In: SOMA 2005. Proceedings of the IX Symposium on Mediterranean Archaeology. (Chieti, Italy, Feb. 24-26, 2005). Ed. by O. Menozzi, M. L. Di Marzio, and D. Fossataro. Vol. 1739. BAR International Series. Oxford, England: Archaeopress Publishers of British Archaeological Reports, 2008, pp. 267-274.

76. Le Quellec, J. L. "Prehistory in North Africa after the Middle Palaeolithic". In: The Cambridge World Prehistory. Africa, South and Southeast Asia and the Pacific. Ed. by C. Renfrew and P. Bahn. Vol. 1. Cambridge: Cambridge University Press. 2014 Chap. 1.10, pp. 151-164.

77. Linstädter, J., Eiwanger, J., Mikdad, A., and Weniger, G. C. “Human occupation of Northwest Africa: A review of Middle Palaeolithic to Epipalaeolithic sites in Morocco". Quaternary International 274, 2012, 158-174. DOI: 10.1016/j.quaint.2012.02.017.

78. Barton, N. and Bouzouggar, A. "Hunter-gatherers of the Maghreb: 25,000-6000 years ago". In: The Oxford handbook of African archaeology. Ed. by P. Mitchell and P. Lane. Oxford: Oxford University Press, 2013 pp. 431-443. 
79. Rahmani, N. "Technological and cultural change among the last hunter-gatherers of the Maghreb: the Capsian (10,000-6000 B.P.)" Journal of World Prehistory 2004, 18(1), 57-105. DOI: 10.1023/B:JOWO.0000038658.50738.eb.

80. Lubell, D. "Prehistoric edible land snails in the circum-Mediterranean: the archaeological evidence". Petits animaux sociétés humaines. Du complément alimentaire aux ressources utilitaires: XXIVe rencontres internationales d'archéologie et d'histoire d'Antibes, 2004, 77-98.

81. Leighton, R. Sicily before history. An archaeological survey from the Palaeolithic to the Iron Age. Cornell University Press. Ithaca, USA, 1999, ISBN-13: 978-0-8014-8585-5.

82. Lambeck, K., Antonioli, F., Purcell, A. and Silenzi, S. Sea-level change along the Italian coast for the past 10,000 yr. Quaternary Science Reviews 2004, 23(14), 1567-1598. DOI: 10.1016/j.quascirev.2004.02.009.

83. Lambeck, K., Rouby, H., Purcell, A., Sun, Y. and Sambridge, M. Sea level and global ice volumes from the Last Glacial Maximum to the Holocene. Proceedings of the National Academy of Sciences 2014, 111(43), 15296-15303. DOI: 10.1073/pnas.1411762111.

84. Ferranti, L., Antonioli, F., Mauz, B., Amorosi, A., Dai Pra, G., Mastronuzzi, G., Monaco, C., Orrù, P., Pappalardo, M., Radtke, U., Renda, P., Romano, P., Sansò, P. and Verrubbi, V. Markers of the last interglacial sea-level high stand along the coast of Italy: Tectonic implications. Quaternary International 2006, 145-146, 30-54. DOI: 10.1016/j.quaint.2005.07.009.

85. EMODnet (2015). European Marine Observation and Data Network. URL: http://www.emodnet.eu/ (visited on 05/14/2015).

86. Cann, J. R. and Renfrew, C. The Characterization of Obsidian and its application to the Mediterranean Region. Proceedings of the Prehistoric Society (New Series) 1964, 30, 111-133. DOI: 10.1017/S0079497X00015097.

87. Ammerman, A. J., Matessi, C. and Cavalli-Sforza, L. L. Some new approaches to the study of the obsidian trade in the Mediterranean and adjacent areas. In: The Spatial Organisation of Culture. New approaches in archaeology. Ed. by I. Hodder. University of Pittsburgh Press, Pittsburgh, USA, 1978, pp. 179-196.

88. Walter, R. C., Buffler, R. T., Bruggemann, J. H., Guillaume, M. M., Berhe, S. M., Negassi, B., Libsekal, Y., Cheng, H., Edwards, R. L., von Coselk, R., Neraudeau, D. and Gagnon, M. Early human occupation of the Red Sea coast of Eritrea during the last interglacial. Nature 2000, 405, 65-69. DOI: 10.1038/35011048.

89. Tykot, R. H. Obsidian procurement and distribution in the central and western Mediterranean. Journal of Mediterranean Archaeology 1996, 9(1), 39-82. DOI: 10.1558/jmea.v9i1.39.

90. Tykot, R. H. Geochemical analysis of obsidian and the reconstruction of trade mechanisms in the Early Neolithic of the western Mediterranean. In: Archaeological Chemistry. Materials, Methods, and Meaning. Ed. by K. A. Jakes. 2002, Vol. 831, Chap. 11, pp. 169-184. Washington, DC: American Chemical Society. DOI: 10.1021/bk-2002-0831.ch011.

91. Chilardi, S., Copat, V., Mannino, M. A., and Zampetti, D. Nuovi dati sul Paleolitico superiore nel territorio di Erice: la Grotta del Maltese e la Grotta San Francesco. In: Dai ciclopi agli ecisti. Società e territorio nella Sicilia preistorica e protostorica. Atti della XLI Riunione Scientifica. (San Cipirello (PA), Nov. 16-19, 2006). Firenze: Istituto italiano di Preistoria e Protostoria, 2012, pp. 403-414.

92. Nicoletti, F. and Tusa, S. Nuove acquisizioni scientifiche sul Riparo del Castello di Termini Imerese. In: Dai ciclopi agli ecisti. Società e territorio nella Sicilia preistorica e protostorica. Atti della XLI Riunione Scientifica. (San Cipirello (PA), Nov. 16-19, 2006). Firenze: Istituto italiano di Preistoria e Protostoria, 2012, pp. 303-318.

93. Mulazzani, S., Le Bourdonnec, F.-X., Belhouchet, L., Poupeau, G., Zoughlami, J., Dubernet, S., Tufano, E., Lefrais, Y. and Khedhaier, R. Obsidian from the Epipalaeolithic and Neolithic eastern Maghreb. A view from the Hergla context (Tunisia). Journal of Archaeological Science 2010, 37(10), 2529-2537. DOI: doi:10.1016/j.jas.2010.05.013.

94. Nicoletti, F. Il commercio preistorico dell'ossidiana nel Mediterraneo e il ruolo di Lipari e Pantelleria nel più antico sistema di scambio. In: Prima Sicilia. Alle origini della società siciliana. (Albergo dei Poveri. Palermo, Dec. 18-22, 1997). Ed. by S. Tusa. Vol. 1. Siracusa: Arnaldo Lombardi Editore, pp. 259-273.

95. Trump, D. H. and Cilia, D. Malta Prehistory and Temples. Midsea Books, Malta, 2002, ISBN 978-9990993943.

96. Oddone, M. and Bigazzi, G. Studi di provenienza delle ossidiane del bacino del Mediterraneo: Caratterizzazione delle fonti naturali di materia prima italiane. Journal of Intercultural and Interdisciplinary Archaeology 2003, 1, F/01 [16 pages]. URL:

http://v01.jiia.it/JIIA.it/Sezione_II/IIIA 01/Oddone-Bigazzi_F01/Articolo_F01/Oddone-Bigazzi_pag1.html. 
97. Aranguren, B. and Revedin, A. Il giacimento mesolitico di Perriere Sottano (Ramacca, CT). Bollettino di Paletnologia Italiana 1998, 89, 31-79.

98. Martini, F., Lo Vetro, D., Colonese, A., Di Giuseppe, Z., Forzisi, V., Giglio, R., Ricciardi, and S., T. S. Primi risultati sulle nuove ricerche stratigrafiche a Grotta di Oriente (Favignana, Tp). Scavi 2005. In: Dai ciclopi agli ecisti. Società e territorio nella Sicilia preistorica e protostorica. Atti della XLI Riunione Scientifica. (San Cipirello (PA), Nov. 16-19, 2006). Firenze: Istituto italiano di Preistoria e Protostoria, 2012, pp. 319-332.

99. Abelli, L., Agosto, M. V., Casalbore, D., Romagnoli, C., Bosman, A., Antonioli, F., Pierdomenico, M., Sposato, A., and Chiocci, F. L. Marine geological and archaeological evidence of a possible pre-Neolithic site in Pantelleria Island, Central Mediterranean Sea". In: Geology and Archaeology: Submerged Landscapes of the Continental Shelf. Ed. by J. Harff, G. Bailey, and F. Lüth. 2014, Vol. 411. Special Publications. First published online September 19, 2014. London: The Geological Society. DOI: 10.1144/SP411.6.

100. Rapisarda, M. L'età dell'ossidiana di Pantelleria. Atti della Accademia Peloritana dei Pericolanti. Classe di Scienze Fisiche, Matematiche e Naturali 85(2), C1C0702001 [21 pages], 2007. DOI: 10.1478/C1C0702001.

101. Orsi, G. Geology and volcanism of Pantelleria. In: Annual Workshop of the Working Group of the European Seismological Commission, Seismic Phenomena Associated with Volcanic Activity, Field Trip. (Sept. 23-28, 2003). Pantelleria, Sicily.

102. Civetta, L., Cornette, Y., Crisci, G., Gillot, P. Y., Orsi, G. and Requejo, C. S. Geology, geochronology and chemical evolution of the island of Pantelleria". Geological Magazine 1984, 121(06), 541-562. DOI: $10.1017 /$ S0016756800030703.

103. Francaviglia, V. M. Ancient obsidian sources on Pantelleria (Italy). Journal of Archaeological Science 1988, 15(2), 109-122. DOI: 10.1016/0305-4403(88)90001-5. 